\title{
Effective suppression of Dengue fever virus in mosquito cell cultures using retroviral transduction of hammerhead ribozymes targeting the viral genome
}

\author{
Pruksa Nawtaisong ${ }^{1,2}$, James Keith ${ }^{1}$, Tresa Fraser ${ }^{1}$, Velmurugan Balaraman ${ }^{1}$, \\ Andrey Kolokoltsov ${ }^{3}$, Robert A Davey ${ }^{3}$, Stephen Higgs ${ }^{4}$, \\ Ahmed Mohammed ${ }^{1}$, Yupha Rongsriyam² ${ }^{2}$, Narumon Komalamisra ${ }^{2}$ and \\ Malcolm J Fraser Jr*1
}

Address: ${ }^{1}$ Department of Biological Sciences, Eck Institute of Global Health, University of Notre Dame, Notre Dame, Indiana 46556, USA, ${ }^{2}$ Department of Medical Entomology, Faculty of Tropical Medicine, Mahidol University, Bangkok, Thailand, ${ }^{3}$ Department of Microbiology and Immunology, University of Texas Medical Branch, Galveston, Texas, 77555, USA and ${ }^{4}$ Department of Pathology, Center for Biodefense and Emerging Infectious Diseases, University of Texas Medical Branch, Galveston, Texas, 77555, USA

Email: Pruksa Nawtaisong - eightam@gmail.com; James Keith - jkeith@albany.edu; Tresa Fraser - fraser.4@nd.edu; Velmurugan Balaraman - vbalaram@nd.edu; Andrey Kolokoltsov - aakoloko@utmb.edu; Robert A Davey - radavey@UTMB.EDU; Stephen Higgs - sthiggs@UTMB.EDU; Ahmed Mohammed - amohoammed00@yahoo.com; Yupha Rongsriyam - r_yupha@hotmail.com; Narumon Komalamisra - fraser.1@nd.edu; Malcolm J Fraser* - fraser.1@nd.edu

* Corresponding author

Published: 4 June 2009

Virology Journal 2009, 6:73 doi:10.1186/1743-422X-6-73

This article is available from: http://www.virologyj.com/content/6/I/73

(C) 2009 Nawtaisong et al; licensee BioMed Central Ltd.

This is an Open Access article distributed under the terms of the Creative Commons Attribution License (http://creativecommons.org/licenses/by/2.0), which permits unrestricted use, distribution, and reproduction in any medium, provided the original work is properly cited.
Received: 6 August 2008

Accepted: 4 June 2009

\begin{abstract}
Outbreaks of Dengue impose a heavy economic burden on developing countries in terms of vector control and human morbidity. Effective vaccines against all four serotypes of Dengue are in development, but population replacement with transgenic vectors unable to transmit the virus might ultimately prove to be an effective approach to disease suppression, or even eradication. A key element of the refractory transgenic vector approach is the development of transgenes that effectively prohibit viral transmission. In this report we test the effectiveness of several hammerhead ribozymes for suppressing DENV in lentivirus-transduced mosquito cells in an attempt to mimic the transgenic use of these effector molecules in mosquitoes. A lentivirus vector that expresses these ribozymes as a fusion RNA molecule using an Ae. aegypti tRNAval promoter and terminating with a $60 \mathrm{~A}$ tail insures optimal expression, localization, and activity of the hammerhead ribozyme against the DENV genome. Among the 14 hammerhead ribozymes we designed to attack the DENV-2 NGC genome, several appear to be relatively effective in reducing virus production from transduced cells by as much as 2 logs. Among the sequences targeted are 10 that are conserved among all DENV serotype 2 strains. Our results confirm that hammerhead ribozymes can be effective in suppressing DENV in a transgenic approach, and provide an alternative or supplementary approach to proposed siRNA strategies for DENV suppression in transgenic mosquitoes.
\end{abstract}




\section{Background}

Dengue viruses (DENV); (Flaviviridae), etiologic agents of dengue fever (DF) and dengue hemorrhagic fever/dengue shock syndrome (DHF/DSS), are transmitted to human populations by the mosquitoes Aedes aegypti and Ae. albopictus. An estimated 50-100 million cases of DF are reported each year, with 500,000 cases of DHF/DSS and more than 20,000 deaths [1]. Several factors that contribute to the emergence of this disease complex include the collapse of mosquito vector control, the demise of public health programs, mosquito drug resistance, climatic changes, expanding urbanization and increased global travel and commerce $[2,3]$. While promising vaccine candidates are undergoing clinical trials [4], these vaccines will not be available for general use for quite some time.

Alternative strategies targeting DENV in mosquito cells and tissues have demonstrated some promise for suppression of the virus in mosquito vector populations. Modified antisense oligonucleotides [5], induction of RNA interference (RNAi) using both preM-derived sense and antisense encoding sequences expressed from dsSIN virus vectors $[6,7]$ and hairpin dsRNA to mediate RNAi in both mosquito cells $[8,9]$ and transgenic mosquitoes [10,11] have each provided significant levels of DENV suppression.

While RNAi may be an effective mechanism to interrupt viral infection, it also has several potential limitations. Targeted sequences must be at least 21 nt in length limiting the number of target sequences that are conserved among all DENV strains, and escape mutants can result from a single point mutation among the $21 \mathrm{nt}$ of target sequence [12]. RNAi requires a relatively large amount of dsRNA to be effective against viral replication [13], and some viruses may replicate faster than the ability of the RNAi response to suppress the virus [3]. A number of plant and animal RNA viruses effectively escape the RNAi response by encoding proteins that suppresses RNA silencing $[10,14,15]$. Flaviviruses, in particular, seem to evade the RNAi response by sequestering their replication complex inside a double-layered membrane complex [11].

In an attempt to overcome some of these limitations of RNA-based effector strategies, our lab has focused efforts on RNA-enzyme (ribozyme) mediated viral suppression. In this report we explore the utility of a genetic approach utilizing hammerhead ribozymes ( $\mathrm{hRz}$ ) for suppression of DENV in mosquito cells. hRz can inhibit the replication of a number of RNA viruses including human immunodeficiency virus (HIV; [16,17], hepatitis B virus (HBV; $[18,19]$ and hepatitis C virus (HCV; [20]. These molecules are capable of identifying targets as small as $15 \mathrm{nt}$ in length, potentially allowing highly conserved sequences to be the focus of attack.

In this report we transduced Ae. albopictus (C6/36) cells with pantropic retroviral vectors, each expressing one of 14 anti-DENV hRz driven from the Ae. aegypti tRNAval promoter. These ribozyme-transduced cells were challenged with virus and assayed for productivity. Northern analyses, immunofluorescence assays, and quantitative realtime PCR demonstrate that C6/36 cells expressing several hRzs were able to suppress DENV replication by at least $75 \%$, with four of these hRzs providing 90 to $99 \%$ suppression. Several of these targeted sequences are highly conserved among DENV serotypes, and may facilitate the application of this approach to transgenic mosquitoes.

\section{Results \\ Construction of retroviral transducing vectors expressing anti-DENV hRzs and establishment of transduced C6/36 cells}

$\mathrm{hRz}$ are small ribonucleic-based enzymes that are capable of catalyzing target RNA cleavage in a sequence-specific manner. Their mechanism of action involves the pairing of the 5' helix I and 3' helix III arms of the hRz to complementary 3' and 5' base pairs, respectively, on the target RNA (Fig. 1A). The catalytic core of the hRz, or helix II, is responsible for cleavage at a 5'-NUH-3' triplet site on the target RNA, where $\mathrm{N}$ can be any of the four nucleotides and $\mathrm{H}$ can be A, C or U [21]. Factors that contribute to the success of hRzs as effector genes include (i) high concentration and stability of the hRz within the cellular environment, (ii) colocalization of the hRzs to the target RNA $[22,23]$ and (iii) accessibility of the hRzs to the cleavage site within the context of RNA secondary structure [24]. The addition of a tRNA ${ }^{\mathrm{val}}$ pol III promoter upstream of the $\mathrm{hRz}$-coding sequence ensures high production of $\mathrm{hRz}$ transcripts and facilitates their transport to the cell cytoplasm [25], overcoming the rate-limiting step of the $\mathrm{hRz}$ cleavage mechanism.

We identified the Ae. aegypti tRNAval sequence from the GenBank database based upon homology to the Drosophila melanogaster tRNA ${ }^{\mathrm{val}}$ sequence. The presumptive Ae. aegypti tRNA ${ }^{\text {val }}$ (GenBank accession: CC142986), shared a $95 \%$ similarity $\left(e=5 \times 10^{-27}\right)$ to the $D$. melanogaster tRNAval, including both internal promoter sites (Fig. 1B). This sequence was PCR amplified from Ae. aegypti genomic DNA and placed into a pLXRN vector upstream of inserted hRz sequences as detailed in Materials and Methods. A stretch of 60 adenylic acids (A) was linked downstream from the $\mathrm{hRz}$ sequences to enhance their catalytic activity by interacting with intracellular RNA helicases $[26,27]$ and improving access to target sites on the viral genome (Fig. 1C). 
A.

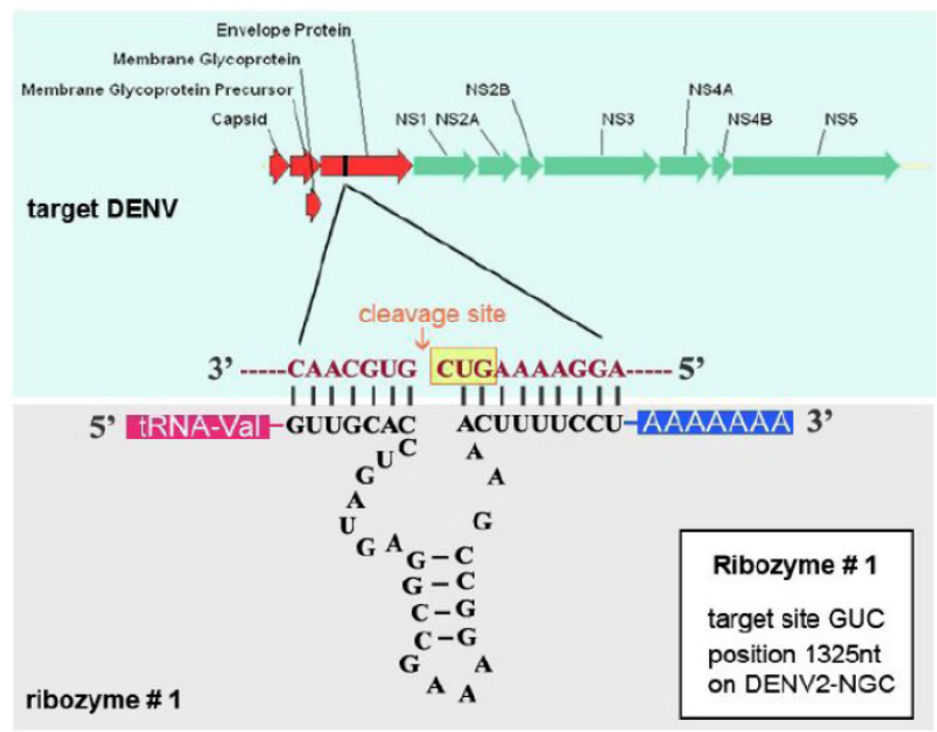

B.

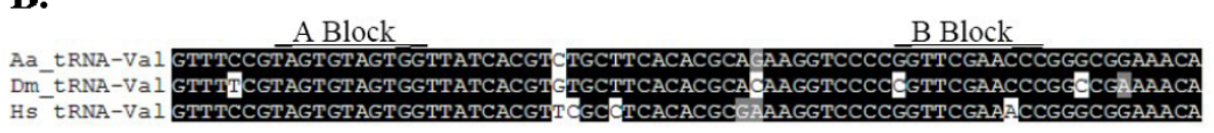

C.

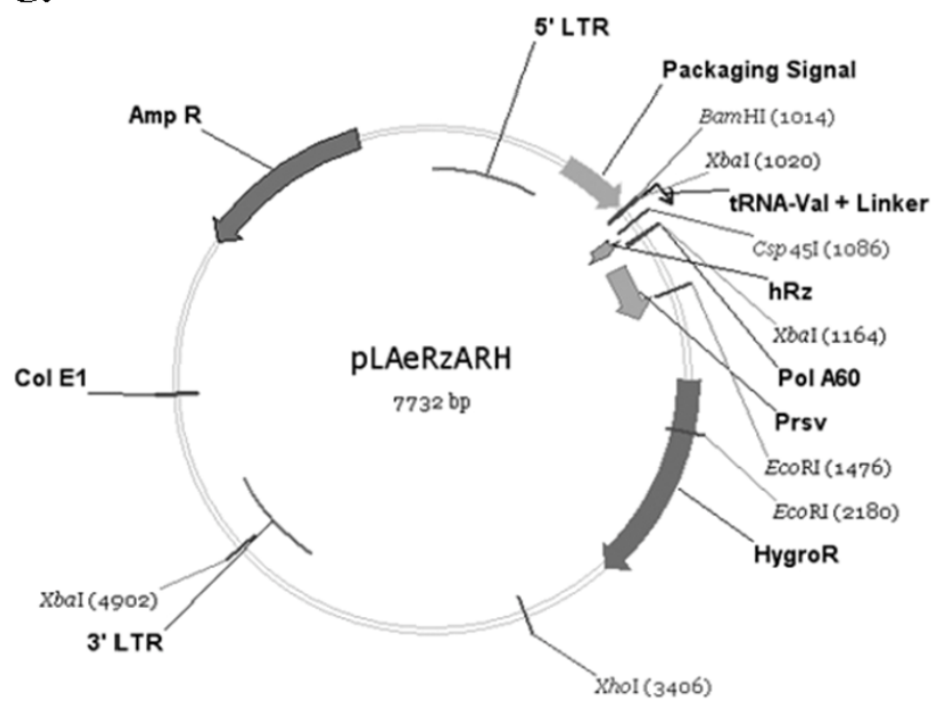

Figure I

A: Representative hRz structure and its DENV target sequence. $h R z$ \# I nucleotide sequence and structure is depicted. Nucleotides flanking the cleavage site (yellow box) in the envelope protein region of the DENV-2 target RNA are enlarged. The ribozyme cleaves the target RNA at the GUC triplet site following antisense recognition and base pairing of the two ribozyme arms. B: Nucleotide alignments of the Human (Hs), D. melanogaster (Dm), and Ae. aegypti (Aa) tRNAval. The position of the concensus internal $A$ and $B$ blocks of the RNA pol III promoter are indicated. C: Plasmid pLAeRzARH was derived from pLXRN as described in Materials and Methods. The RSV promoter was added to drive independent expression of the

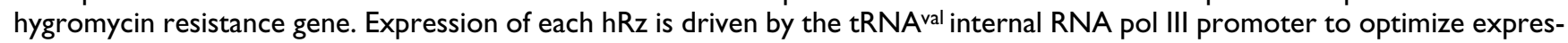
sion and translocation of the hRzs to the cytoplasm, and a stretch of 60As is attached to the $3^{\prime}$ end of the hRz sequence for recruitment of RNA helicase. 
Fourteen ribozyme-encoding retroviruses and one control lacking a ribozyme sequence were used to transduce wildtype C6/36 cells by infecting at an MOI of 30 as described in Materials and Methods. Retrovirus-infected C6/36 cells were placed under hygromycin selection for 4-8 weeks and then analyzed for $\mathrm{hRz}$ expression by RT-PCR of total cellular RNA (Fig. 2). Only cells that are transduced will have integrated provirus cDNA transcribing the hRz RNA. Therefore, we can be certain that the detected RNA is not residual lentivirus genomic RNA.

\section{CPE of DENV infection in the hRz-transduced C6/36 cells}

The CPE of DENV-2 NGC infection in C6/36 cells, characterized by syncytium formation and decreased cell proliferation, was clearly visible 5 days post infection (dpi). Those cells expressing certain hRz exhibited a clear reduction in CPE at $5 \mathrm{dpi}$, allowing them to grow to confluency, while cells that lack hRz, (i.e. No-hRz and wild-type), exhibited the expected CPE (Fig. 3). The most effective
$\mathrm{hRz}$ constructs were those that appeared to completely suppress CPE. These were hRz-C6/36 cell lines \# 2, 5, 7 and 11 .

\section{Northern analyses for DENV genome}

Those transduced cultures that gave at least moderate CPE suppression were analyzed by Northern blot with DENVspecific probes to determine the impact of $\mathrm{hRz}$ expression on DENV RNA replication. Infected and uninfected wildtype C6/36 cells were included as positive and negative controls, respectively, with $\beta$-actin serving as an internal hybridization and loading control. Autoradiographs (Fig. $4 \mathrm{~A}$ and $4 \mathrm{~B}$ ) were scanned and analyzed by densitometry to estimate the relative amounts of DENV RNA in each sample.

The rapid degradation of ribozyme cleavage products coupled with the very effective suppression of DENV replication in the transduced cells, made detection of $\mathrm{hRz}$

A.

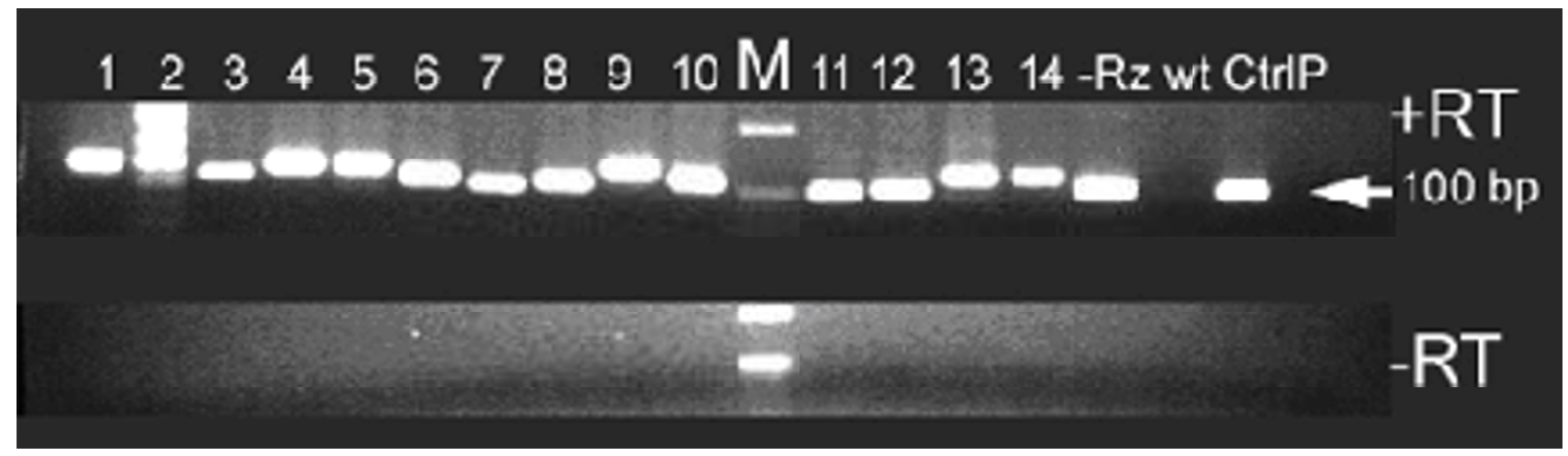

B.

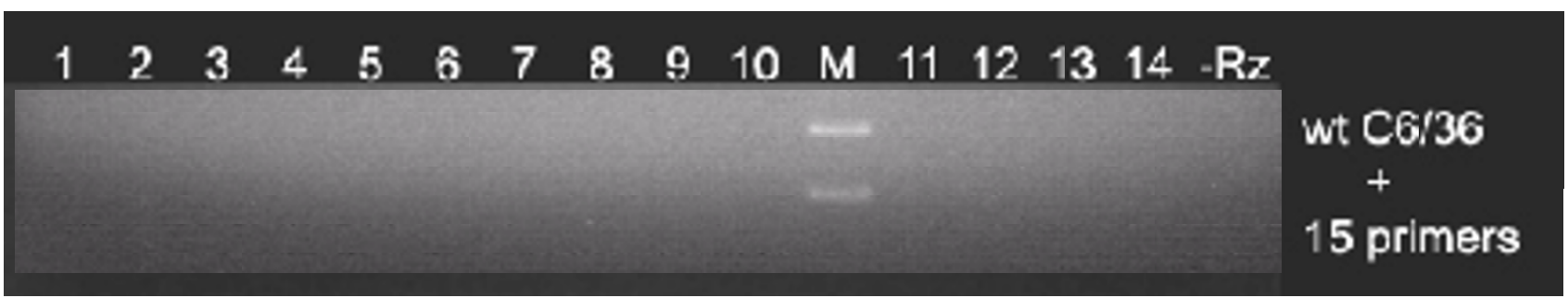

\section{Figure 2}

RT-PCR of total RNA extracted from hRz-C6/36 cells. (A) hRz expression in the cells was detected by the presence of an $\mathrm{hRz}$-specific band at about $100 \mathrm{bp}$. Primers for each $\mathrm{hRz}-\mathrm{C} 6 / 36$ cells were specific to the $\mathrm{hRz}$ insert except for the control lacking a $h R z$ sequence $(-R z)$ for which the primers were specific to tRNAval and poly $(A)$ tail. (B) Wild-type C6/36 cells failed to give a PCR product when tested with 15 sets of primers (each primer was specific to each hRz). I-I4: I4 different hRz-C6/36 cells; -Rz: C6/36 cells without the hRz insert; wt: wild-type C6/36 cells; CtrlP: plasmid DNA control for PCR amplification; M: I $\mathrm{Kb}$ Plus DNA ladder; $+R T$ : reactions with reverse transcriptase; $-R T$ : reactions without reverse transcriptase. 


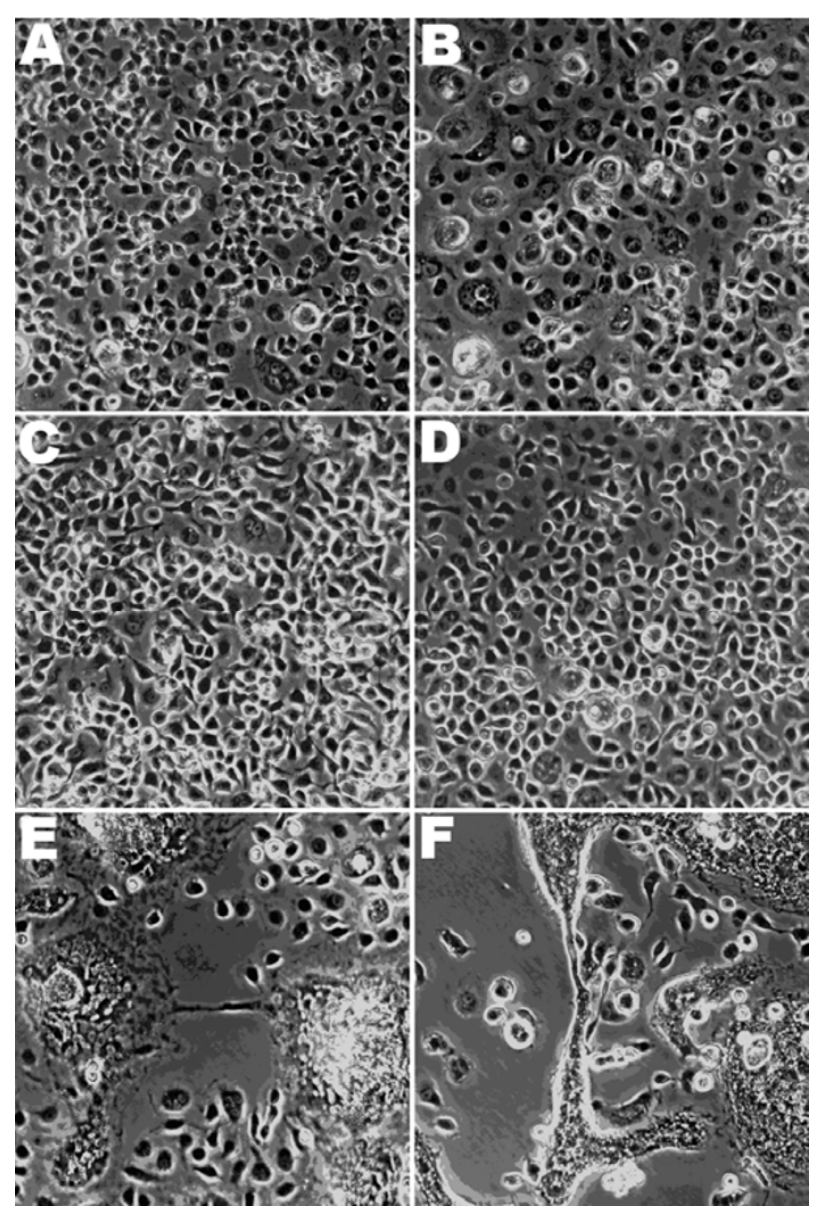

Figure 3

CPE due to DENV infection of $\mathbf{C 6 / 3 6}$ cells at $5 \mathrm{dpi}$. Images were taken at the $40 \times$ magnification. Cells were those transduced with $\mathrm{hRz}$-encoding retroviruses and selected in hygromycin for stable integration of the transgene. Representative infected cell cultures are shown. These are cells transduced with (A) $h R z \# 2$, (B) $h R z \# 5$, (C) $h R z \#$ 7 , (D) $h R z$ \# II , (E) No Rz (transduced with lentivirus vector lacking a hRz) or (F) non-transduced $\mathrm{C} 6 / 36$ cells.

cleavage product RNAs difficult by Northern blots. The efficacy of the hRzs was estimated by comparing the relative amount of the target DENV RNA to the infected and uninfected C6/36 control cultures (Fig. 4C). These analyses confirm that hRz-C6/36 cell lines \# 2, 5, 7 and 11 suppressed the replication of DENV by at least $25 \%$ relative to the infected wild-type cells.

\section{In vitro analyses of $h R z$ cleavage activity}

Because the Northern analyses did not allow detection of ribozyme cleavage products, we tested the four most effective ribozymes for their cleavage activity in vitro. DNA molecules encoding each $\mathrm{hRz}$ construct, including the tRNA ${ }^{\text {val }}$ and polyA tail, were synthesized downstream of a T7 promoter sequence, cloned, and expressed in vitro as

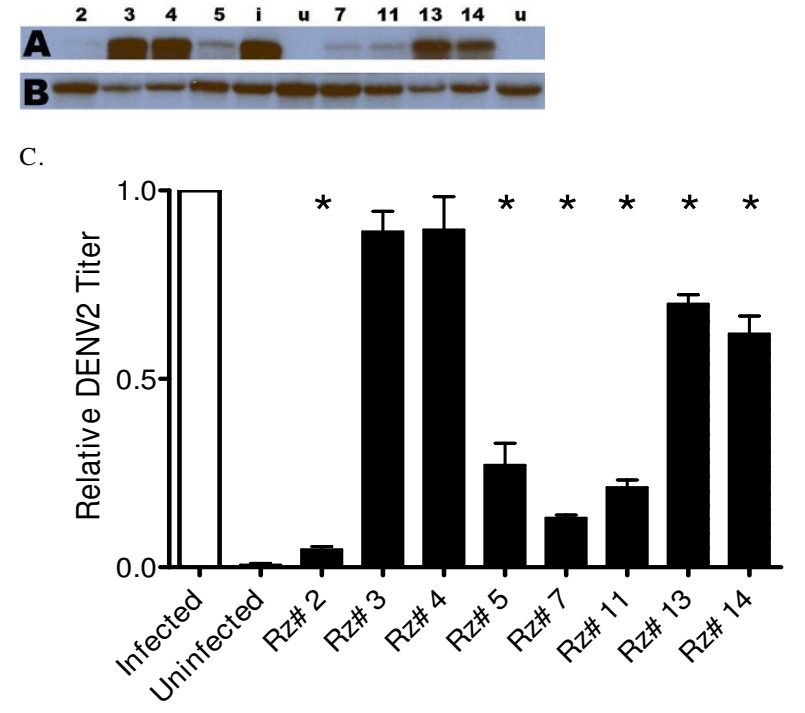

Figure 4

Northern hybridization analysis of DENV-2 replication in cells expressing $\mathbf{h R z}$ constructs. (A) Total RNA samples hybridized with DENV-specific probes. (B) Actin RNA from the same samples hybridized with a $\beta$-actin-specific probe. Each construct is indicated by numbers; $i$ : wildtype C6/36 infected with DENV; u: uninfected wild-type C6/ 36. The autoradiograph was exposed for $6 \mathrm{hr}$ prior to developing. (C) Quantification of relative DENV-2 RNA levels from the Northern blot analysis. The scanned autoradiograph was processed in ImageJ software and the relative amount of DENV-2-specific RNA in each sample was compared against that of infected wild-type cells using an ANOVA test (GraphPad Prism 3.0). Statistically significant differences relative to the Infection control (Dunnett's posttest, $\mathrm{p}<0.0 \mathrm{I}$ ) are indicated with asterisks. Infected: infected, non-transduced $\mathrm{C} 6 / 36$ cells; Uninfected: uninfected, nontransduced C6/36 cells; $R z$ \#: Different infected $\mathrm{hRz}$ cells.

described in Materials and Methods. These in vitro transcribed ribozymes were combined with in vitro transcribed target RNA molecules containing extensive regions of the DENV-2 NGC genome that encompass hRz \# 2 and 5, or $\mathrm{hRz} \# 7$ and 11 cleavage sites. The results for two of these ribozymes, hRz \# 2 and \# 7, are presented in Fig. 5. The cleavage products and hRzs are apparent as distinct bands in the lanes corresponding to each reaction. A third band of unknown identity was detected in each experimental lane as well. We believe this extra fragment is the result of alternative cleavage of the target RNA since the size of the $\mathrm{hRz}$ transcripts (50 nt) are too small to appear on these gels, and because these fragment do not appear in the control lanes lacking hRz.

\section{$T C I D_{50}$ immunofluorescence assays}

We determined the effectiveness of each ribozyme in suppressing overall infectious virus production using an immunoflourescence-based $\operatorname{TCID}_{50}$ assay. Cell culture 


\section{A. Target DENV-Envelope region}

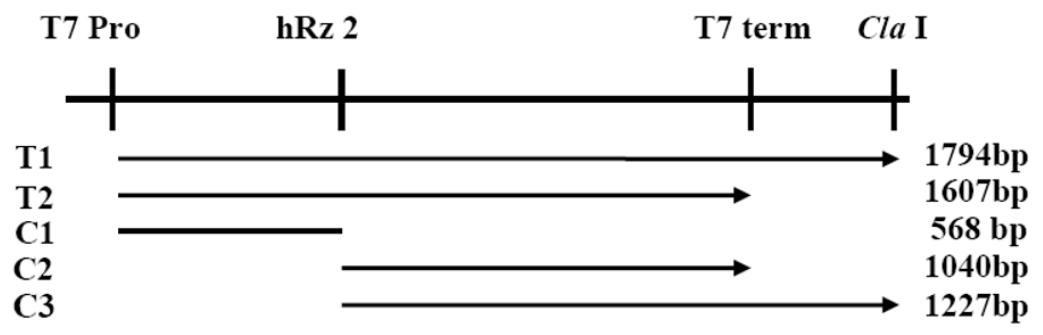

\section{B. Target DEV-3'NCR region}

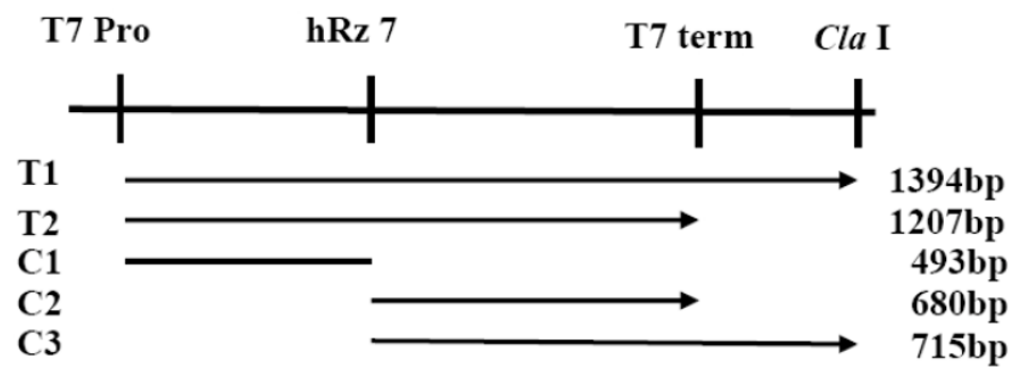

C.

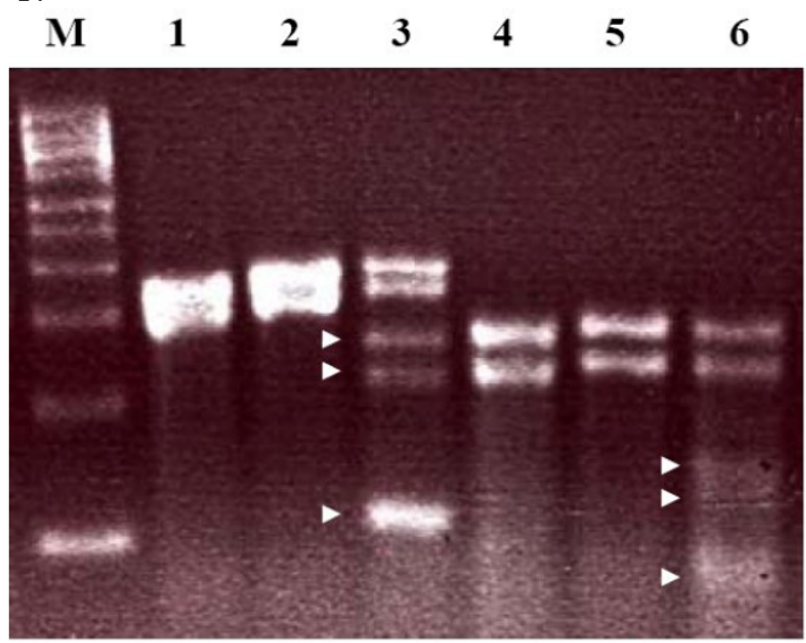

\section{Figure 5}

Confirmation of cleavage activities for representative hRzs. (A and $B$ ) Maps showing the in vitro transcripts generated from the linearized pETI la vectors for the hRz \# 2 (A) and hRz \# 7 (B) target substrates. Positions of the T7 promoter (T7Pro), hRz-T7 cleavage site (hRz7), T7 terminator (T7 Term), and Cla I site used for linearization (Cla I) are indicated. TI and T2 show the extent of two transcripts that are generated in the in vitro transcription reaction for each substrate. $\mathrm{Cl}$ shows the extent of the single 5' cleavage product from both transcripts from each substrate, while C2 and C3 show the extent of the two 3' cleavage products generated from the two different transcripts produced from each substrate. (C) Agarose gel of in vitro cleavage reaction products. In vitro transcribed targets and their respective hRz \# 2 and hRz \# 7 were incubated for 30 min at $37^{\circ} \mathrm{C}$. Cleavage products were separated in $2 \%$ agarose gels stained with ethidium bromide. Lane M: Millenium ${ }^{\mathrm{TM}}$ RNA Marker. Lanes I-3: In vitro transcribed DENV-ENV region target without $\mathrm{MgCl}_{2}$ (lane I), hRz \# 2 and without $\mathrm{MgCl}_{2}$ (lane 2), and hRz \# 2 with $\mathrm{MgCl}_{2}$ (lane 3). Lanes 4-6: In vitro transcribed 3'NCR region target without $\mathrm{MgCl}_{2}$ (lane 4), hRz \# 7 without $\mathrm{MgCl}$ (lane 5 ), and hRz \# 7 with $\mathrm{MgCl}_{2}$ (lane 6). Arrows in lanes 3 and 6 show the expected hRz \# 2 and hRz\#7 cleavage products, respectively. 
medium collected at $4 \mathrm{dpi}$ from infected cells was assayed as described in Materials and Methods using a DENV envelope protein-specific monoclonal antibody. While all ribozyme transformed, and even the No-hRz transformed control cells, exhibited statistically significant reductions in overall infectious virus production, hRz-C6/36 cell lines \# 2, 5, 7 and 11 had remarkably reduced DENV-2 titers, as much as 2 orders of magnitude, compared to infected wild-type cells (Table 1 and Fig. 6). The fact that the No-hRz control did have reduced yields of virus can be attributed to the hygromycin selection protocol, which did impact the virus infectivity in transformed cells to some extent.

\section{Real-time PCR quantitation of DENV titer in whole cell RNA}

The ability of each hRz to suppress DENV genome replication was quantitatively evaluated for the $\mathrm{hRz}$ expressing C6/36 cells using qRT-PCR to detect virus genomes in cell lysates. Total cellular RNA was extracted $7 \mathrm{dpi}$ from infected hRz-transduced cells following the protocol described in Materials and Methods. First-strand cDNA was prepared using the Capsid2 primer (Table 2), followed by 40 rounds of PCR amplification using primers Capsid2 $\mathrm{F}$ and $\mathrm{R}$. The absolute quantity of viral RNA was determined based upon comparison of infected cell $\mathrm{Ct}$ values against those of viral RNA standards.

Table I: Tabulation of data for $\operatorname{TCID}_{50}$ and $q R T-P C R$ analyses of $h R z$ effectiveness

\begin{tabular}{|c|c|c|c|c|c|c|c|}
\hline & \multicolumn{2}{|c|}{ TCID50 } & \multicolumn{2}{|c|}{ qRT-PCR Cells } & \multicolumn{2}{|c|}{ qRT-PCR Supernatant } & \multirow[b]{2}{*}{ Avg \% Red } \\
\hline & Avg & SE & Avg & SE & Avg & SE & \\
\hline Infected & $4.39 \times 10^{6}$ & $7.12 \times 10^{5}$ & $1.77 \times 10^{6}$ & $4.17 \times 10^{5}$ & $2.92 \times 10^{6}$ & $1.38 \times 10^{6}$ & 0 \\
\hline Uninfected & 2 & 1 & 3 & 2 & 3 & 1 & $\mathrm{~N} / \mathrm{A}$ \\
\hline No-hRz & $1.88 \times 10^{6}$ & $5.94 \times 10^{5}$ & $1.37 \times 10^{6}$ & $2.53 \times 10^{5}$ & $1.60 \times 10^{6}$ & $6.46 \times 10^{5}$ & 41.71 \\
\hline Rz \# I & $8.77 \times 10^{5}$ & $3.4210^{6}$ & $1.62 \times 10^{6}$ & $3.13 \times 10^{5}$ & $9.46 \times 10^{5}$ & $2.70 \times 10^{5}$ & 52.03 \\
\hline $\mathrm{Rz} \# 2$ & $2.78 \times 10^{4}$ & $1.09 \times 10^{4}$ & $5.88 \times 10^{4}$ & $3.95 \times 10^{4}$ & $5.37 \times 10^{4}$ & $1.65 \times 10^{4}$ & 98.07 \\
\hline $\mathrm{Rz} \# 3$ & $1.16 \times 10^{6}$ & $6.8910^{5}$ & $1.68 \times 10^{6}$ & $3.38, \times 10^{5}$ & $1.39 \times 10^{6}$ & $7.62 \times 10^{5}$ & 43.62 \\
\hline $\mathrm{Rz} \# 4$ & $2.37 \times 10^{6}$ & $1.14 \times 10^{6}$ & $1.99 \times 10^{6}$ & $2.61 \times 10^{5}$ & $1.51 \times 10^{6}$ & $7.58 \times 10^{5}$ & 27.39 \\
\hline $\mathrm{Rz} \# 5$ & $3.08 \times 10^{4}$ & $9.1 \times 10^{3}$ & $9.65 \times 10^{4}$ & $4.90 \times 10^{4}$ & $9.44 \times 10^{4}$ & $2.18 \times 10^{4}$ & 96.87 \\
\hline $\mathrm{Rz} \# 6$ & $2.33 \times 10^{5}$ & $1.16 \times 10^{5}$ & $1.65 \times 10^{6}$ & $1.97 \times 10^{5}$ & $6.45 \times 10^{5}$ & $1.76 \times 10^{5}$ & 59.74 \\
\hline Rz \# 7 & $2.72 \times 10^{4}$ & $1.13 \times 10^{4}$ & $9.56 \times 10^{4}$ & $2.04 \times 10^{4}$ & $4.98 \times 10^{4}$ & $2.49 \times 10^{4}$ & 97.42 \\
\hline $\mathrm{Rz} \# 8$ & $1.87 \times 10^{5}$ & $1.26 \times 10^{5}$ & $6.46 \times 10^{5}$ & $2.51 \times 10^{5}$ & $4.95 \times 10^{5}$ & $2.43 \times 10^{5}$ & 80.76 \\
\hline Rz \# 9 & $8.50 \times 10^{4}$ & $3.46 \times 10^{4}$ & $2.51 \times 10^{5}$ & $1.24 \times 10^{5}$ & $3.24 \times 10^{5}$ & $1.45 \times 10^{5}$ & 90.92 \\
\hline Rz \# 10 & $4.07 \times 10^{5}$ & $2.34 \times 10^{5}$ & $5.11 \times 10^{5}$ & $1.39 \times 10^{5}$ & $1.36 \times 10^{5}$ & $4.71 \times 10^{4}$ & 85.74 \\
\hline Rz \# II & $2.47 \times 10^{4}$ & $4.01 \times 10^{3}$ & $3.55 \times 10^{4}$ & $1.59 \times 10^{4}$ & $2.11 \times 10^{4}$ & $7.41 \times 10^{3}$ & 98.90 \\
\hline Rz \# 12 & $5.49 \times 10^{5}$ & $1.61 \times 10^{5}$ & $5.51 \times 10^{5}$ & $3.17 \times 10^{5}$ & $3.43 \times 10^{5}$ & $2.06 \times 10^{5}$ & 81.54 \\
\hline Rz \# 13 & $3.06 \times 10^{5}$ & $1.08 \times 10^{5}$ & $3.60 \times 10^{5}$ & $2.11 \times 10^{5}$ & $1.90 \times 10^{5}$ & $1.65 \times 10^{5}$ & 88.73 \\
\hline Rz \# 14 & $1.98 \times 10^{5}$ & $1.22 \times 10^{5}$ & $2.63 \times 10^{5}$ & $1.07 \times 10^{5}$ & $2.63 \times 10^{5}$ & $2.20 \times 10^{5}$ & 90.53 \\
\hline
\end{tabular}

Averages of results from four separate infections (Avg) are presented for each type of analysis along with Standard Error of the Mean (SE). The average percent reduction for all tests (Avg \% Red) relative to the Infected cell control is calculated in the final column. 


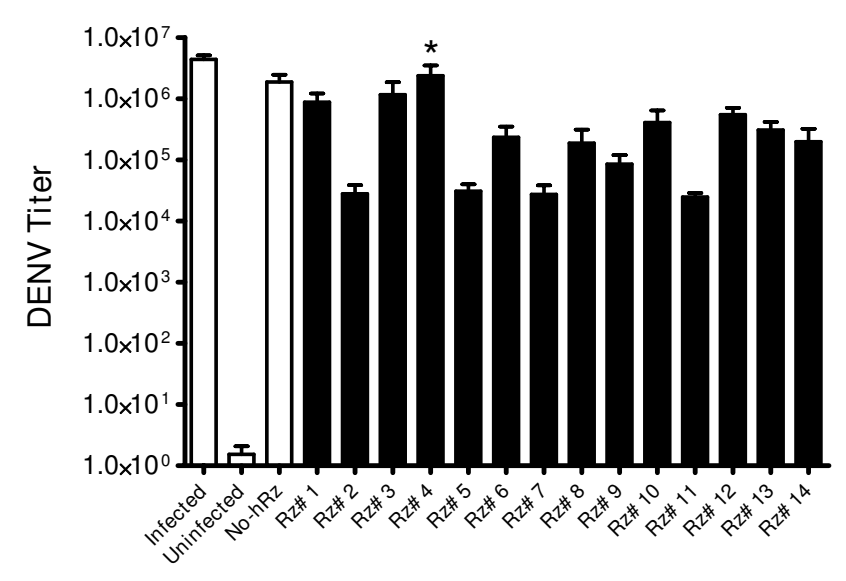

Figure 6

TCID $_{50}$ immunofluorescence assay. At 4 day dpi, cells were fixed and stained. Primary antibody against ENV protein and biotinylated-secondary antibody and streptavidin were employed as a fluorescence detection system. A oneway ANOVA test was performed using GraphPad Prism 3.0 software. Asterisk indicate no significant differences relative to the Infected control (Dunnett's, $p<0.01$ ). Rz \# I-I4: I4 different infected hRz cells; No Rz: infected C6/36 cells transduced with the lentivirus vector lacking a $\mathrm{hRz}$ insert.

Four independent experiments were compared for each hRz-C6/36 transduced cell line to insure consistency and reproducibility. The results (Table 1 and Fig. 7A) for most of the hRz were consistent with the IFA determination of virus titer, with hRz-C6/36 cell lines \# 2, 5, 7 and 11 exhibiting suppression of DENV replication by up to nearly 100 fold compared to the infected wild-type samples. However, the results for $\mathrm{hRz} \# \mathbf{6}$ were remarkably different from those obtained with the IFA analysis, suggesting this ribozyme may be interfering with viral genome packaging or assembly rather than replication.

\section{Real-time PCR quantitation of DENV titer in cellular medium}

To evaluate the impact of hRzs on assembly and release of DENV, we performed qRT-PCR on the viral RNA extracted from cell supernatant of the infected hRz-C6/36 cells. Cell supernatants collected at one hour prior to whole cell RNA extraction were immediately processed for RNA extraction, cDNA synthesis and RT-PCR procedures (see Materials and Methods). The results (Table 1 and Fig. 7B) demonstrated that the titers of extracellular virus genomic RNA obtained for hRz-C6/36 cell lines \# 2, 5, 7 and 11 were consistent with genome copies detected in whole cell extracts. Similar levels of reduction were seen for most of the other hRz as well. Together, these qRT-PCR findings confirmed that most of the highly effective hRzs affected viral RNA replication and not DENV assembly and release from the cells.

The levels of extracellular virion RNA for hRz \# 6 were more closely related to the TCID ${ }_{50}$ results than to the qRTPCR results of total cellular RNA, reinforcing the possibility that this ribozyme's effect was related to interference with virion production rather than direct suppression of viral genomes.

\section{Discussion}

We have confirmed the effectiveness of expressed hRzs as suppressive agents of DENV in transduced mosquito cells. These ribozymes have the ability to cleave their target RNA at an NUH triplet site, and may recycle themselves provided there are short sequence homologies between the ribozyme arms and the corresponding target sequence. This could provide an advantage over standard antisense RNAs that act stoichiometrically and do not destroy the function of the targeted RNAs [28].

In this study, the ribozymes were expressed under the control of the Ae. aegypti tRNAval promoter. Human tRNAval

Table 2: Designations and base sequences of twelve primer sets evaluated to select optimal primer pairs for detection of the DENV-2 NGC RNA genome

\begin{tabular}{lll}
\hline Designation & Primer sequences $\left(\mathbf{5}^{\prime} \rightarrow \mathbf{3}^{\prime}\right)$ & \\
\hline CapsidI & 2F: caatatgctgaaacgcgaga & 2R: ccatcactgttggaatcagc \\
Capsid2 & 3F: caatatgctgaaacgcgaga & 3R: cgccatcactgttggaatc \\
Capsid3 & 4F: gcgagaaatacgcctttcaa & 4R: ccatcactgttggaatcagc \\
Capsid4 & 5F: tatgctgaaacgcgagagaa & 5R: cgccatcactgttggaatc \\
Capsid5 & 6F: gcgagaaatacgcctttcaa & 6R: cgccatcactgttggaatc \\
Capsid6 & 7F: atgctgaaacgcgagagaaac & 7R: ccctgctgttggtgggatt \\
NS5I & 2F: tcaaaagcattcagcacctg & 2R: cacatttgggcgtaggactt \\
NS52 & 3F: gcaatgtatgccgatgacac & 3R: caggtgctgaatgcttttga \\
NS53 & 4F: gcaatgtatgccgatgacac & 4R: tcaggtgctgaatgcttttg \\
NS54 & 5F: tggaggagccttagtgagga & 5R: acgtcccaaggttttgtcag \\
NS55 & 6F: tgagcaagaaagagggagga & 6R: caggtgctgaatgcttttga \\
NS56 & 7F: caaaagcattcagcacctgaca & 7R: gttaaagcgcttgcgaacct \\
\hline
\end{tabular}

F and R: forward and reverse primer, respectively. 
A.

Real-Time PCR: Infected cells

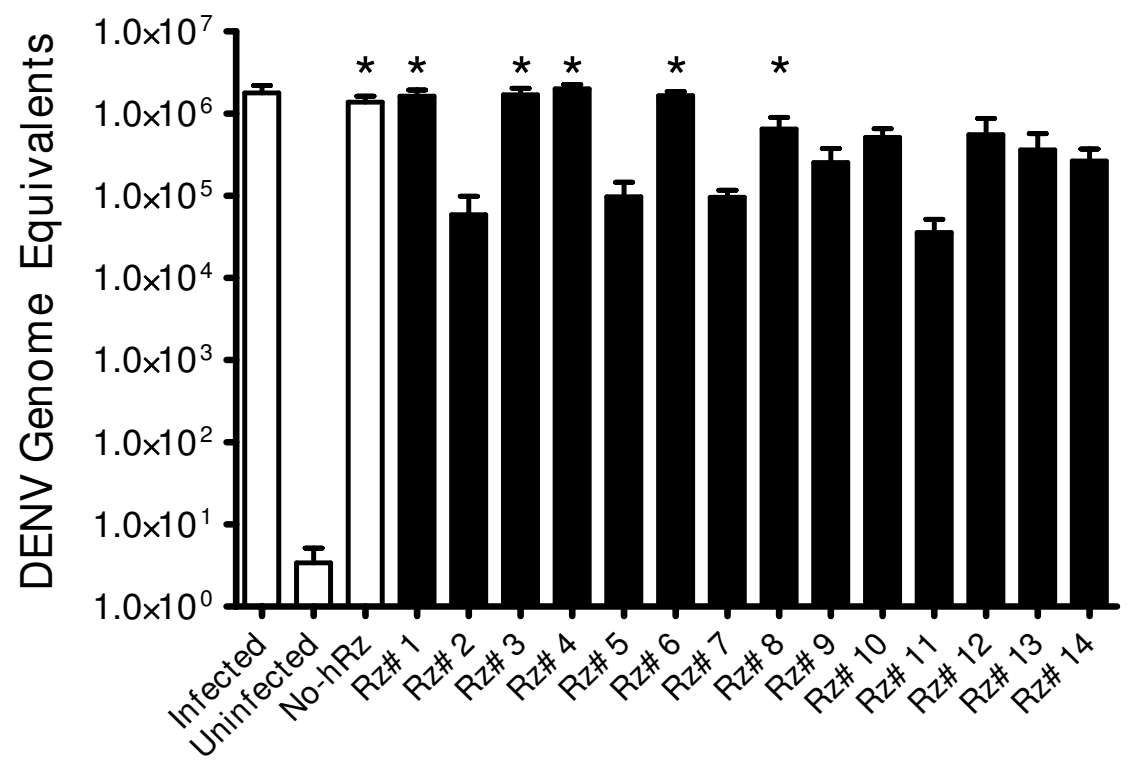

B.

Real-Time PCR: Cell supernate

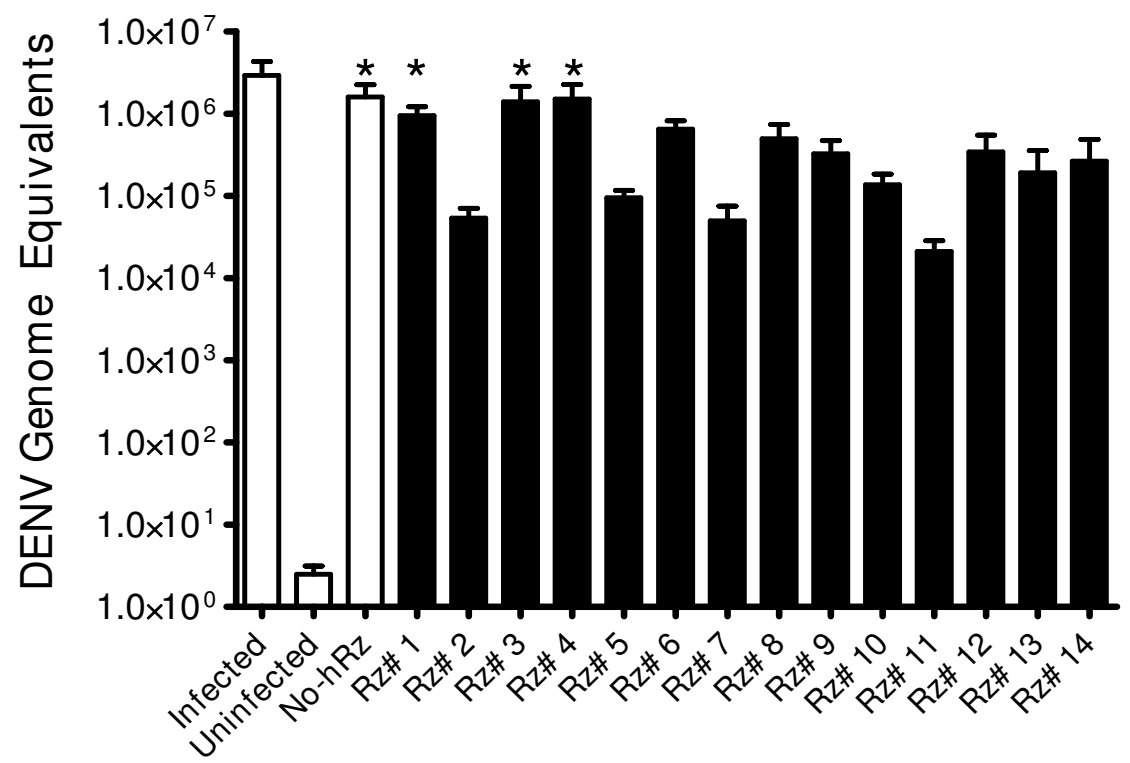

Figure 7

A: Absolute quantitation of genome equivalents in cells infected with DENV and expressing hRzs. Viral RNA samples were obtained from total cell RNA extraction at 7 dpi. ANOVA test was performed using GraphPad Prism 3.0 software. Asterisk indicate no significant differences relative to the Infected control (Dunnett's, $P<0.0 \mathrm{I}$ ). Plot is based on the average titer from 4 independent experiments. Rz \# I-I4: 14 different infected hRz cells; No Rz: infected C6/36 cells transduced with the lentivirus vector lacking a $h R z$ insert. B: Absolute quantitation of viral titers from different $h R z$ cells. Viral RNA samples were obtained from collected cell supernatant at 7 dpi. ANOVA test was performed using GraphPad Prism 3.0 software. Asterisk indicate no significant differences relative to the Infected control (Dunnett's, $\mathrm{P}<0.0 \mathrm{I}$ ). Rz \# I-I4: I4 different infected hRz cells; No Rz: infected C6/36 cells trasnduced with the lentivurs vector lacking a $\mathrm{hRz}$ insert. Plots are based on the average titer from 4 independent experiments. 
has been used successfully to enable suppression of target genes by driving the expression of hRzs $[29,30]$. The tRNAval utilizes RNA pol III which is involved in the transcription of short RNAs [31] and yields transcription levels 23 orders of magnitude greater than that of pol II systems [32]. Linking hRzs to a tRNAval also enhances their activity by increasing resistance to RNases, since intracellular stability is one of the most important determinants of ribozyme efficacy [33], and facilitates the cytoplasmic transport of the attached ribozyme [25] where it can be co-localized with replicating DENV RNA.

Since intramolecular base pairing within the complex structure of the long DENV genomic RNA could preclude the association of ribozymes with their target sequences, we designed our hRz to include a 3' terminal 60 adenylic acids. This poly(A) sequence acts to recruit the unwinding activity of endogenous RNA helicase [34]. Hybrid ribozymes with this poly(A) tail are able to cleave target RNAs possessing complex secondary structure that hRz without accessory helicases cannot act upon $[26,35]$. In addition, the effect of helicase-attached hRzs is significantly greater than those of the conventional parental ribozymes [27].

Retroviral vectors offer a number of advantages over other gene transfer methods for the transduction of somatic cells, and have been widely used as gene delivery systems. They have the ability to stably integrate the genes they vector into host cell chromosomes with high transduction efficiencies [36-38]. Pseudotyped retroviruses displaying the vesicular stomatitis virus G glycoprotein (VSV-G) are able to transduce any dividing cells without the requirement for cell receptors [39]. This pantropic retroviral system has been successfully employed for transduction of mosquito cells [40]. In our experiments, we used self-inactivating retrovirus vectors having a defective 3 ' U3 that is duplicated as part of the $5^{\prime}$ LTR during reverse transcription, allowing the $\mathrm{hRz}$ transgene to be expressed by the internal tRNAval promoter and decreasing the possibility of promoter interference [36,41]. Transduced hRz cells were selected for hygromycin resistance for longer than 2 months. Though it is likely that less than $100 \%$ of these resistant cells were transformed, the majority of them appear to bear functional hRz vectors within the genome as indicated by the RT-PCR results of expressed hRz RNA. In addition, because these cells were transduced using lentivitus vectors, there is no real possibility that expression of the hRz came from the non-integrated vector.

Transduction of C6/36 cells by means of pantropic retrovirus vectors resulted in stable genomic integration and expression of the hRzs, rendering them persistently resistant to DENV. Since pools of transduced cells were used for the DENV challenge assays, the observed inhibition effects are not likely due to clonal variation or differing copy number of the constructs within the transduced cell population. However, this approach does allow the possibility that individual cells in the pools may be more susceptible to DENV and thus contribute to the majority of virus detected. In addition, the lower antiviral activity seen for some hRzs might also reflect a distribution effect leading to a wide range of $\mathrm{hRz}$ expression levels in the transduced cell cultures $[17,42]$.

We designed $14 \mathrm{hRzs}$ that target different regions along the DENV-2 genome. Quantitative real-time PCR and immunofluorescence assays demonstrate that $\mathrm{C} 6 / 36$ cells expressing certain hRzs were able to suppress DENV-2 NGC viral replication by at least $25 \%$, with hRz-C6/36 cell lines \# 2, 5, 7 and 11 having a more pronounced effect, of nearly 2 logs (100 fold) reduction in viral titer compared to the untransduced C6/36 cells. These IFA results correspond well with data obtained from the Northern hybridization analyses for those hRzs examined.

We were unable to detect the cleaved RNA products by Northern analyses due to two factors. First, there is likely rapid degradation of the DENV RNA within the cells after they are cleaved. Second, the hRz expressing cells are "armed" with many hRz molecules, and upon infection by the virus there is little chance for initiation of a productive infection during which DENV target RNA might build up to levels that cleavage products might become apparent. We interpret these results to demonstrate that suppression of virus, when it occurs, is so effective that little new viral RNA target is actually produced, and few cleavage products would be expected to be evident.

With the exception of hRz \# 11, the three most active hRzs target the GUC triplet site which is cleaved most efficiently compared to other triplets [43]. GUC is frequently chosen as the target in many hRz studies because of its wide occurrence in natural hRz motifs [28]. The No-hRz transduced cells, which lack the hRz insert, exhibited no significant suppression of DENV replication, verifying that decreased levels of viral titers requires the presence of the $\mathrm{hRz}[44]$ and is not simply due to the presence of the transducing retrovirus or hygromycin selection.

$\mathrm{Ng}$ et al. reported $12 \%$ reduction of the $\mathrm{krr} 1$ gene expression in Giardia canis in cells without a hRz motif and attribute the observation to an antisense effect of the $\mathrm{hRz}$ forming a complex with the mRNA, inhibiting its translation and promoting its degradation [45]. While we cannot rule out an antisense effect for our hRzs, the in vitro analyses of ribozyme cleavage activity demonstrated that they were catalytically active. Hence, the cleavage activity of 
ribozymes within cellular environments would be expected to occur. The reduction in functional full-length DENV RNA was consistent with the cleavage effects of the ribozymes since the effectiveness of the hRzs we examined correlates very well with the realative effectiveness of the core cleavage site in that three of the four most effective hRzs target a GUC triplet, supporting the catalytic nature of the hRzs effectiveness and arguing against a simple antisense effect.

For the most part, the variations in relative effectiveness that we observed among the $14 \mathrm{hRz}$ we analyzed can be explained by less efficient cleavage activity resulting in incomplete inhibition of DENV replication. However, there are several alternative possibilities unrelated to $\mathrm{hRz}$ catalysis that could influence their effectiveness. These include (i) the presence of mismatched bases in the $\mathrm{hRz}$ arm, especially with shorter effectors [46], due to viral escape mutants, (ii) integration of the $\mathrm{hRz}$ construct into an inactive gene expression region of the host cell genome, and (iii) obscuring of the target triplet site by RNA-binding proteins $[28,47]$. Since our experiments were done over a short time frame and with multiple replicates we can rule out the selection of escape mutations as the cause of weak suppression. Our RT-PCR analyses of the expressed hRz RNA in transformed cells did not show an appreciable difference in levels of expression, allowing us to rule out position effects on expression levels as a factor. The only possibility we cannot rule out in our experiments is the interference by RNA binding proteins at the target site.

hRz \# 6 exhibited a somewhat different result from all other hRzs when comparing the relative levels of DENVspecific RNA between cellular and extracellular RNAs by qRT-PCR. The results for hRz \# 6 suggest cellular DENVspecific RNA levels were not reduced to comparable levels as extracellular DENV-specific RNA levels. This implies that the reductions in virus titer observed with hRz \# 6 are not related to reductions in viral RNA synthesis in infected cells, but may result from affects on packaging of the viral genomes and/or assembly and release of virions. Because $\mathrm{hRz}$ \# 6 was not among the most effective hRzs tested, we did not pursue examination of this phenomenon.

While we were able to target several sequences that are common to all DENV serotype 2 strains, we were unable to identify suitable cleavage sites that were conserved among all DENV serotypes. Several highly conserved sequences are present among all DENV serotypes, but the requirement for an NUH triplet cleavage site makes these conserved sequences useless as targets for the hRz strategy. Other ribozymes having less stringent cleavage site requirements may be more appropriate for these conserved sequences.

Our results are comparable with results obtained from sense/antisense and siRNA strategies for suppression of DENV. dsSIN may be used in transient expression systems to validate these strategies in either cell cultures or mosquitoes $[6,7]$ but retroviral vectors and transduced mosquito cells are more appropriate for examining the effectiveness of transgene suppression strategies in somatic cells because they allow a closer approximation of the actual endpoint of these strategies, transgenic mosquito tissues. Our results suggest the best application of this effector molecule is to constitutively express the hRz in target cells since DENV undergoes rapid RNA synthesis at 3-6 hours post infection and release of infectious virions after 12 hours. Transgenic cells pre-primed with expressed hRzs are able to act instantly in inhibiting viral replication upon entry.

Neither our hRz approach nor the siRNA strategy is wholey effective against viral escape mutants. However, one potential obstacle in using RNAi is the evidence for viral RNAi suppressors which have been reported in plants, poliovirus, and HIV-1 variants [48-50]. In the case of DENV, the presence of viral RNAi suppressors may contribute to persistent infections in which DENV is able to replicate in cells without causing cytopathic effect. hRzs are not subject to suppression by viral gene products, which could be an advantage when applied as an antiDENV effector gene.

A number of RNA viruses exhibit significant genetic variation due to error-prone replication machinery. The simultaneous use of multiple ribozymes attacking two or more sites on the same target RNAs may be advantageous since it helps minimize loss of ribozyme activity due to basepairing mismatches from mutation of one or the other targeted sites. However, simultaneous expression of two different ribozymes within the same transduced cell pool did not enhance the reduction of DENV titers (data not shown). Our results indicate the same levels of inhibition as obtained with the single hRz approach. This lack of synergy when two independent hRzs area employed might be caused by structural changes within the target RNA following the cleavage by one $\mathrm{hRz}$ that alter the cleavage domain for the second $\mathrm{hRz}$, interfering with its ability to anneal with the substrate. Similar results have been reported by Xu et al., 1999, in which the expression of human insulin-like growth factor II is not completely inhibited by double hRzs but yields the same efficacy as single hRzs. As an alternative approach, we are currently exploring combining two hRzs as a so-called Maxizyme 
$[25,29,30,51,52]$ that targets two regions with low tolerance for sequence variation, and may ultimately provide even better suppression of DENV replication in transduced mosquito cells and tissues.

Our results demonstrate that the hRz approach has significant potential as a strategy for suppressing DENV in transgenic mosquitoes, either alone or in combination with alternative genetic suppression strategies. While complete suppression of virus infectivity in infected mosquito tissues may not be possible, significant reduction of virus titers within mosquito tissues could result in a decreased efficiency of transmission for the virus, thereby reducing the prevalence of the disease among associated human populations.

\section{Materials and methods}

\section{Ae. aegypti $t$ RNAval identification}

We used the tRNA ${ }^{\mathrm{val}}$ sequence identified by the fruit fly genome survey (NT_037436 REGION: complement (1342674613426818)) as a query for a BLASTN search. We limited our search to Ae. aegypti instances in the Genome Survey Sequence database. The search returned one hit bearing a $95 \%$ similarity $\left(e=5 \times 10^{-27}\right)$ to the $D$. melanogaster tRNAval, including both internal promoter sites. We then used the mFold [53] software and found the typical cloverleaf structure indicative of tRNA folding. We then added the extended stem region used by Kuwabara et al. [30] and analyzed the predicted folding pattern with mFold again.

\section{Selection of $h R z$ target sites on DENV-2 genome}

Genomic sequences of 29 strains of DENV-2 were retrieved from GenBank, aligned in ClustalX [54,55], and $\mathrm{hRz}$ target sites were selected by scanning for conserved sequences that contain one of the following triplets; GTC, GTA, ATC or CTC. These triplets are believed to be the most effective target sites for $\mathrm{hRz}$ cleavage activity [28]. The primary criterion for selection was that the target site must be present in all 29 strains of DENV-2 (DENV-2$\mathrm{hRz}$ ), or present only in DENV-2 NGC (DENV-2 NGC$\mathrm{hRz}$ ). Another important criterion for selecting suitable sites for hRz cleavage was the length of conserved flanking arms which determine the level of specificity of the ribozyme. In this study, the length of each arm ranges from 5-10 bp. The sequences of hRz templates, positions of the triplets on DENV genome, and the specific strains of DENV-2 NGC they match are listed in Table 3.

Table 3: Sequence, positions, and tropism of each of the 14 ribozymes used in this study

\begin{tabular}{|c|c|c|c|}
\hline hRz \# & Sequence of target RNA $\left(5^{\prime} \rightarrow 3^{\prime}\right)$ & Target triplet and position in genome & DENV-2 strains targeted \\
\hline 1 & AGGAAAAGUCGUGCAAC & GUC I 325 (ENV) & NGC \\
\hline 2 & GUUUUAGGUCGCCUGAU & GUC 1988 (ENV) & NGC \\
\hline 3 & UAGCCCAGUCAACAUAG & GUC 2035 (ENV) & NGC \\
\hline 4 & CAUAGGAGUCAUUAUCA & GUC 2323 (ENV) & NGC \\
\hline 5 & UCACUGUCUGUGUC & GUC 2367 (ENV) & All strains \\
\hline 6 & AUAGUGUCAUCAGUGAA & GUC 8272 (NS5) & All strains \\
\hline 7 & AAAGAAGUCAGGCCA & GUC 10420 (3'NCR) & All strains \\
\hline 8 & GCAUGGUACCUGUGG & GUA 4503 (NS2B) & All strains \\
\hline 9 & GACUCAAAACUCAUGUCAGC & CUC 2974 (NSI) & All strains \\
\hline 10 & AUGGAAAUCAGACCATT & AUC 3430 (NSI) & All strains \\
\hline 11 & GGAAGCUGUACGCAUGG & GUA I0528 (3'NCR) & All strains \\
\hline 12 & UGAAGCUGUAGUCUC & GUA I0624 (3'NCR) & All strains \\
\hline 13 & AUGCCAUCCAUGAA & AUC 10244 (NS5) & All strains \\
\hline 14 & CUGUUGAAUCAACAGGU & AUC 10768 (3'NCR) & All strains \\
\hline
\end{tabular}

Underlined: core NUH triplet 


\section{Plasmid construction}

The hRz expression plasmid, pLAeRzARH (Figure 1), contains a given hRz-encoding gene under the control of the Ae. aegypti tRNAval promoter. This is followed by a 60As tail that promotes $\mathrm{hRz}$ accessibility. A hygromycin resistance gene under control of a Rous Sarcoma Virus (RSV) promoter permits selection of transfected cells. The backbone was derived from pQCXIH retroviral vector (Clontech, Mountain View, CA). To assemble this construct, pQCXIH was digested with $\mathrm{Xba}$ I and $E c o$ R V to eliminate the original IRES-hygromycin fragment from the plasmid. The RSV promoter was amplified from pLXRN (Clontech) using the following primer set; forward 5' TAAT TCTAGACCGTGCGGCCGCAGATCCCCTCAGGATATAGTAGT TTC 3' and reverse 5' ACCAGATATCACGCGTGCGAAACGATCCTCATCCTGTCTCTT 3'. The PCR product was isolated from a $0.9 \%$ agarose gel using the QIAquick Gel Extraction Kit (Qiagen, Valencia, CA). The amplified RSV promoter was inserted into the digested vector at the Xba I and EcoR V sites to create pQCXR. The hygromycin resistance gene was amplified by PCR from pQCXIH using the following primers; forward 5' ATCGACGCGTATGGATAGATCCGGAAAGCCTGAA CTCA C CGCGACG 3' and reverse 5' ATCGACGCGTCCCC CCT TTTTCTGGAGACTAAATAAAATCTT 3'. The amplified product was purified as above and inserted into pQCXR between the Mlu I and EcoR V sites to obtain pQCXRH. pQCXRH was then cut with $\mathrm{Xba}$ I and treated with antarctic phosphatase (AP) (New England Biolabs (NEB), Ipswitch, MA) to reduce self-ligation. The 60As tail was constructed by performing a one-cycle PCR amplification using a forward primer: 5' ATCGTCTAGAAAAAAAAAAA AAAAAAAAAAAAAAAAAAAAAAAAAAAAAAAAAAAAAAA AAAAAAAAAATTTTTTACTAGTCGTA 3', which also acted as a PCR template, and a reverse primer: 5' TACGACTAGTAAAAAATTTTTTTTTTTTT 3'. The PCR product was directly purified by phenol-chloroform extraction and ethanol precipitation and double digested with Xba I and Spe I before ligating with pQCXRH linearized with Xba I to create pQCARH. Our novel Ae. aegypti tRNAval promoter gene was synthesized from two oligonucleotides using Klenow large fragment DNA polymerase (NEB) and a pair of primers; forward - 5' ATCGTCTAGACCGT TGG TTTCCGTAGTGTAGTGGTTATCACGTCTGCTTCACACGCAGAAGGTCCCCGGTTCGAACCC 3' and reverse - 5' ATCGTCTAGACGATCAATTGCAGTCTCGAGAAAGTTTG GTTTTTGTAGTGCCCGGGTTCGAACCGGGGACCTTCTGCG 3'. The amplified product was purified as above, digested and ligated into pQCARH at the unique Xba I site. To achieve higher packaging efficiency, the entire insert spanning the Ae. aegypti tRNAval promoter to the hygromycin resistance gene was inserted into pLXRN (Clontech). The RSV-neomycin resistance gene originally present in pLXRN was eliminated by digestion with Sph I and Csp45 I, followed by end-filling with Klenow fragment and ligation. To obtain pLAeARH, the region from
Ae. aegypti tRNAval promoter to the hygromycin resistance gene from pQAeARH was amplified by PCR using the following primer set; forward 5' ATTAGGATCCTCTAGACCGTTGGTTTCCGTAGTG $3{ }^{\prime}$ and reverse 5' ATTACCTA GG GATATCCTGTCTTTAACAAATTGGACTAATC 3 ' and inserted into the modified pLXRN plasmid using Avr II and BamH I sites. hRz genes were then inserted between Csp45 I and Mfe I sites. hRz templates (Table 4) were amplified using the following set of primers; forward 5' ATCGACGCGTATGGATAGATCCGGAAAGCCTGAACTC ACCGCGACG 3' and reverse 5' GATGAATTCAAAAAA ACAA TTGT 3'. The PCR product was purified as above and cut with Csp45 I and $M f e$ I before insertion into pLAeARH, generating pLAeRzARH. Restriction analysis and DNA sequencing were performed after each cloning step to confirm correct base sequences. All plasmids were purified by $\mathrm{CsCl}_{2}$ gradient centrifugation.

\section{Retroviruses}

Retroviruses encoding the 14 hRzs and No-hRz control were produced following established methods [56]. Briefly, the retroviruses were assembled by simultaneous transfection of 293FT cells (Invitrogen, Carlsbad, CA) with the pLAeRzARH $(5 \mu \mathrm{g})$ and plasmids encoding murine leukemia virus gag-pol $(5 \mu \mathrm{g})$ and the vesicular stomatitis virus (VSV) envelope protein $(2 \mu \mathrm{g})$. The VSV envelope protein confers broad host range and allows high efficiency transduction of the transgene into Aedes cells [39]. After $48 \mathrm{hr}$, culture supernatants containing the retroviruses were collected and filtered through a $0.45 \mathrm{um}$ filter to remove cell debris. Virus was then applied to target cells or stored frozen at $-80^{\circ} \mathrm{C}$ until required.

\section{Cell Culture}

\section{Maintenance}

Ae. albopictus (C6/36) mosquito cells used in this study were maintained in complete L-15 (Atlanta Biologicals) with 10\% FBS (Atlanta Biologicals), 10\% tryptose phosphate broth (Sigma), and 1\% antibiotic/antimycotic solution (Sigma). $\mathrm{hRz}$ transduced cells were maintained in complete L-15 with $35 \mu \mathrm{g} / \mathrm{mL}$ hygromycin (Invitrogen). For infection of cells, complete L-15 without any antibiotics was used. Cells were incubated at $28^{\circ} \mathrm{C}$ without $\mathrm{CO}_{2}$.

\section{Infection with retroviruses and selection of transduced cells} Wild-type C6/36 cells in 6-well plates were infected with retroviruses at an MOI of 30. After $24 \mathrm{hr}$, the medium was replaced and the cells were allowed to grow for one week before being transferred to T25 flasks. Complete L-15 medium with hygromycin B was added to the T25 flasks after 72 hr to select stably transduced cells.

\section{Infection with DENV-2 NGC}

Wild-type C6/36 cells were seeded at a density of $0.5 \times 10^{6}$ cells $/ \mathrm{mL}$ in 6 -well plates and incubated for $2 \mathrm{hr}$ at $28^{\circ} \mathrm{C}$ to allow attachment. Once attached, cells were washed twice 
Table 4: Sequences of the fourteen ribozyme templates used for PCR amplification

\begin{tabular}{|c|c|}
\hline hRz \# & Template sequence for amplification (5' to 3 ') \\
\hline I & $\begin{array}{l}\text { CCGGTTCGAACCCGGGCACTACAAAAACCAACAAgt } \\
\text { tgcacCTGATGAGGCCGAAAGGCCGAAActtttcctA } \\
\text { CAATTGTTTTTTTGAATTCATC }\end{array}$ \\
\hline 2 & $\begin{array}{l}\text { CCGGTTCGAACCCGGGCACTACAAAAACCAACAAat } \\
\text { caggcCTGATGAGGCCGAAAGGCCGAAAcctaaaac } \\
\text { ACAATTGTTTTTTTGAATTCATC }\end{array}$ \\
\hline 3 & $\begin{array}{l}\text { CCGGTTCGAACCCGGGCACTACAAAAACCAACAAct } \\
\text { atgttCTGATGAGGCCGAAAGGCCGAAActgggctaA } \\
\text { CAATTGTTTTTTTGAATTCATC }\end{array}$ \\
\hline 4 & $\begin{array}{l}\text { CCGGTTCGAACCCGGGCACTACAAAAACCAACAAtg } \\
\text { ataatCTGATGAGGCCGAAAGGCCGAAActcctatgA } \\
\text { CAATTGTTTTTTGAATTCATC }\end{array}$ \\
\hline 5 & $\begin{array}{l}\text { CCGGTTCGAACCCGGGCACTACAAAAACCAACAAg } \\
\text { acacaCTGATGAGGCCGAAAGGCCGAAAcagtgaAC } \\
\text { AATTGTTTTTTTGAATTCATC }\end{array}$ \\
\hline 6 & $\begin{array}{l}\text { CCGGTTCGAACCCGGGCACTACAAAAACCAACAAtt } \\
\text { cactgatCTGATGAGGCCGAAAGGCCGAAAcactatA } \\
\text { CAATTGTTTTTTTGAATTCATC }\end{array}$ \\
\hline 7 & $\begin{array}{l}\text { CCGGTTCGAACCCGGGCACTACAAAAACCAACAAtg } \\
\text { gcctCTGATGAGGCCGAAAGGCCGAAActtctttAC } \\
\text { AATTGTTTTTTTGAATTCATC }\end{array}$ \\
\hline 8 & $\begin{array}{l}\text { CCGGTTCGAACCCGGGCACTACAAAAACCAACAAc } \\
\text { cacaggCTGATGAGGCCGAAAGGCCGAAAccatgcA } \\
\text { CAATTGTTTTTTTGATTCATC }\end{array}$ \\
\hline 9 & $\begin{array}{l}\text { CCGGTTCGAACCCGGGCACTACAAAAACCAACAAg } \\
\text { ctgacatCTGATGAGGCCGAAAGGCCGAAAgttttgag } \\
\text { tcACAATTGTTTTTTGAATTCATC }\end{array}$ \\
\hline 10 & $\begin{array}{l}\text { CCGGTTCGAACCCGGGCACTACAAAAACCAACAAa } \\
\text { atggtctCTGATGAGGCCGAAAGGCCGAAAtttccatA } \\
\text { CAATTGTTTTTTTGAATTCATC }\end{array}$ \\
\hline 11 & $\begin{array}{l}\text { CCGGTTCGAACCCGGGCACTACAAAAACCAACAAc } \\
\text { catgcgCTGATGAGGCCGAAAGGCCGAAAcagcttcc } \\
\text { ACAATTGTTTTTTTGAATTCATC }\end{array}$ \\
\hline 12 & $\begin{array}{l}\text { CCGGTTCGAACCCGGGCACTACAAAAACCAACAAg } \\
\text { agacCTGATGAGGCCGAAAGGCCGAAAcagcttcaA } \\
\text { CAATTGTTTTTTTGAATTCATC }\end{array}$ \\
\hline 13 & $\begin{array}{l}\text { CCGGTTCGAACCCGGGCACTACAAAAACCAACAAtt } \\
\text { catgCTGATGAGGCCGAAAGGCCGAAAtggcatACA } \\
\text { ATTGTTTTTTTGAATTCATC }\end{array}$ \\
\hline 14 & $\begin{array}{l}\text { CCGGTTCGAACCCGGGCACTACAAAAACCAACAAa } \\
\text { cctgttCTGATGAGGCCGAAAGGCCGAAAttcaacag } \\
\text { ACAATTGTTTTTTTGAATTCATC }\end{array}$ \\
\hline
\end{tabular}

Bold uppercase: conserved catalytic core. Lowercase: 5' and 3' arms of the $h R z$, respectively. with medium and challenged with DENV-2 NGC stock at an MOI of 0.01. Infection was allowed to continue for 7 days at $28^{\circ} \mathrm{C}$ before viral RNA was extracted both from cells and cultured supernatants using TRI reagent (Invitrogen), and purified QIAamp Viral RNA Mini Kit (Qiagen), respectively.

\section{Northern analysis}

Total RNA was extracted using TRI reagent (Invitrogen), and $10 \mu \mathrm{g}$ was loaded on $1 \%$ denaturing agarose gels. RNA was transferred overnight onto nylon membranes, and the membranes were fixed by UV cross linking, prehybridized in Church Buffer ( $67 \mathrm{~g} \mathrm{Na}_{2} \mathrm{HPO}_{4}, 2 \mathrm{ml} \mathrm{H}_{3} \mathrm{PO}_{4}$, $70 \mathrm{~g}$ SDS in $1 \mathrm{~L}$ distilled water; filter sterilized before use) for an hour, and then hybridized with specific ${ }^{32} \mathrm{P}$-labeled probe overnight in a $65^{\circ} \mathrm{C}$ oven. The membranes were washed $2 \times$ with washing solution 1 ( $2 \times$ SSC, $0.1 \%$ SDS), and another $2 \times$ with washing solution $2(0.2 \times$ SSC, $0.1 \%$ SDS), each wash at $65^{\circ} \mathrm{C}$ for $25-30$ minutes. The DNA probes were designed to detect different regions along the virus genome and were synthesized using Prime-A-Gene Kit (Promega, Madison, WI). Unincorporated unlabelled nucleotides were removed by QIAquick Gel Extraction Kit (Qiagen) before use. The $\beta$-actin gene was used as an internal control for RNA extraction and hybridization. After washing, the autoradiograph was exposed for 6-16 hours before developing. The autoradiograph was scanned and the relative amount of viral RNA in each sample was determined by densitometry using ImageJ Java image processing software http://rsb.info.nih.gov/ij/ index.html. Measurements for each sample were normalized to that of infected wild-type cells to determine the relative virus replication efficiency.

\section{In vitro analysis of $h R z$ cleavage activity}

The procedure for in vitro hammerhed ribozyme cleavage reactions was adapted from Shao Y. et al [57]. Two complementary oligonucleotides containing the hRz catalytic core sequence flanked by the sequences of the two binding arms and a T7 promoter sequence were synthesized (Invitrogen) and annealed together in equimolar concentrations using the following conditions: $10 \mathrm{mM}$ Tris- $\mathrm{HCl}$ $\mathrm{pH} 8.0,50 \mathrm{mM} \mathrm{NaCl}$. The reaction was heat denatured at $95^{\circ} \mathrm{C}$ for $5 \mathrm{~min}$ followed by slow cooling to room temperature. The annealed templates were cloned into the pET11a plasmid (Novagen) and linearized with Cla I for in vitro run-off transcription.

Primer sets were used to PCR amplify a $1370 \mathrm{bp}$ target spanning the 1497-2866 bp envelope region (ENV forward - 5' TTTTAAAATTCTAGAGAGAACGGGCCTCGACTT 3', and reverse - 5' TTTAAATTTAGAT CTCTC TGT TTGTGTTGGGGCATT 3') and a $940 \mathrm{bp}$ target spanning the 9774-10713 bp 3'NCR (NCR forward - 5' AAATTAAAATCTAGAAGTTCCATGCAGAAACCAAG 3', and 
reverse - 5' ATTTTATTTAGATCTGATTCAACAGCACCATTCCA 3') from the DENV-2 NGC Infectious Clone vector. The envelope region contains hRzs \# 2 and 5 sites while the 3 'NCR region contains hRzs \# 7 and 11 sites. The amplified fragments were digested with Xba I and $B g l$ II and cloned into the Xba I and BamH I-digested pET11a vector.

$2.5 \mathrm{ug}$ of linearized ribozyme plasmid and $1.5 \mathrm{ug}$ of ribozyme template were in vitro transcribed using the Megashortscript and Megascript (Ambion, USA), respectively. In vitro transcription reactions were performed following the manufacturer's protocol with incubation for 4 hr at $37^{\circ} \mathrm{C}$. The transcripts were phenol: choloroform: isoamylalcohol (24:25:1) extracted, choloroform: isoamyalcohol (24:1) extracted and ethanol precipitated with 0.2 ug of glycogen. The RNA concentration was measured spectrophotometrically.

In vitro transcribed targets $(10 \mathrm{pM})$ were mixed with 50 pM of ribozymes in $50 \mathrm{mM}$ Tris- $\mathrm{HCl}, \mathrm{pH}-8.0$, heat denatured at $85^{\circ} \mathrm{C}$ for $3 \mathrm{~min}$, and snap cooled in ice. The cleavage reaction was initiated by addition of $20 \mathrm{mM} \mathrm{MgCl}_{2}$, and $40 \mathrm{U}$ of RNase inhibitor and incubated at $37^{\circ} \mathrm{C}$ for 30 min. Loading buffer II (Ambion) was added and the reaction mixture was incubated at $65^{\circ} \mathrm{C}$ for an additional 5 min followed by electrophoresis in a $2 \%$ agarose/formaldehyde/MOPS gel [57] for $1 \mathrm{hr}$ at $105 \mathrm{~V}$. After electrophoresis the gel was stained with ethidium bromide and photographed with UV illumination.

\section{TCID ${ }_{50}$ immunofluorescence assay}

Supernatants containing virus from infected cells were collected 4 dpi and were 10-fold serially diluted in a 96well plate. C6/36 cells from a confluent flask were then added to the mix and the cultures were incubated for 4 days at $28^{\circ} \mathrm{C}$ without $\mathrm{CO}_{2}$. After incubation, cells were fixed with acetone:DPBS $(3: 1)$ and stained with primary antibody $(1: 200)$ specific to the envelope (ENV) protein of DENV [58]. Detection of positive DENV-infected cells was accomplished by utilizing a biotinylated-secondary antibody and streptavidin detection system (Amersham Biosciences, Piscataway, NJ). Cells that showed fluorescence within the cytoplasm were scored as positive for DENV infection. The TCID ${ }_{50}$ was calculated based on Karber's method [59]. The titer was expressed as $\log _{10}$ TCID50/0.1 ml.

\section{Real-Time PCR}

Run mode and machine

All absolute quantitation experiments in this study were performed under the 9600 Emulation run mode of AB7500 Fast machine from Applied Biosystems (Foster City, CA). The PCR profile was 1 cycle of $50^{\circ} \mathrm{C}$ for $2 \mathrm{~min}$, 1 cycle of $95^{\circ} \mathrm{C}$ for $10 \mathrm{~min}$ and 40 cycles of $95^{\circ} \mathrm{C}$ for 15 sec and $60^{\circ} \mathrm{C}$ for $1 \mathrm{~min}$. Dissociation curve analysis was added to the end of each run. This was initiated by heating the PCR product to $95^{\circ} \mathrm{C}$ and holding it for $15 \mathrm{sec}$. Then the denatured DNA was allowed to anneal by ramping down to $60^{\circ} \mathrm{C}$ for $1 \mathrm{~min}$. The temperature was then slowly ramped up again to $95^{\circ} \mathrm{C}$ for $15 \mathrm{sec}$ and fluorescence signal was collected during this time. Once the temperature reached $95^{\circ} \mathrm{C}$, the PCR run was terminated. Results were analyzed using the company's Sequence Detection Software Version 1.3.

\section{Determination of $h R z$ retroviral titers}

Retroviral RNA was extracted using the QIAamp Viral RNA Mini Kit (Qiagen) following the manufacturer's protocol without any modification. The primers used to detect retroviral transcripts were specific to a region corresponding to the packaging signal of the retrovirus. Standard curves were generated based upon known titers of a control virus, pLeGFP, for which the titer was determined by counting GFP expressing cells in a limiting dilution assay $\left(3 \times 10^{6}\right.$ colony forming units per $\mathrm{ml}$ ).

\section{Evaluation and selection of the primer set used for detection of DENV-2 NGC RNA}

Viral RNA was extracted from infected C6/36 cells 7 dpi using QIAamp Viral RNA Mini Kit (Qiagen). Twelve sets of primers were evaluated for detection of the capsid and NS5 regions of the DENV-2 NGC RNA viral genome (Table 2). All primers were designed using the Primer3 freeware website http://frodo.wi.mit.edu/cgi-bin/ primer3/primer3 www.cgi. An optimal primer pair was chosen based on a standard curve (slope value ranges within -2.8 to -3.2 and $\mathrm{R}^{2}$ value ranges within 0.970 to 0.999 ) and a single specific peak on a dissociation curve generated after the PCR run. Slope values of -3.2 indicated $100 \%$ amplification efficiency and $\mathrm{R}^{2}$ values of 1.000 suggested the perfect fit of standard curve data to a straight line. Dissociation curves were plotted after the run to assure the specificity of the PCR product. Higher peaks displayed at $\mathrm{T}_{\mathrm{m}}$ of $80^{\circ} \mathrm{C}$ indicated a specific PCR product while sub peaks at a lower $\mathrm{T}_{\mathrm{m}}$ represented primer-dimers and non-specific PCR products. The primer pair, forward 5' CAATATGCTGAAACGCGAGA $3^{\prime}$ and reverse 5' CGCCATCACTGTTGGAATC 3', was chosen for further experiments as it offered the highest amplification efficiency and gave a single specific PCR product.

\section{Preparation of DENV-2 standard curve}

Wild-type C6/36 cells were infected with the DENV-2 NGC strain and viral supernatants were collected $7 \mathrm{dpi}$. Virus titers were determined by tissue culture infectious dose $50 \%\left(\mathrm{TCID}_{50}\right)$ immunofluorescence assays using a primary antibody against the virus envelope. Viral RNA was extracted as described above and cDNA was synthesized through reverse transcription with MuLV reverse 
transcriptase (Applied Biosystems) and 5-fold serially diluted for generation of the standard curve.

\section{Preparation of viral RNA samples}

Viral RNA from infected cells was extracted using the TRI reagent (Invitrogen). RNA concentrations were determined spectrophotometrically. Viral RNAs were extracted from collected supernatants as mentioned above. cDNAs of each sample were synthesized as described above, and the titers of DENV from each sample were determined based on a standard curve. The presence of a single specific PCR product was also confirmed via a dissociation curve.

\section{Statistics}

ANOVA test was performed using GraphPad Prism 3.0 software. Means were considered statistically significant when p-values less than 0.01 were obtained with the Dunnett's post-test. Lack of statistical significance with regards to Infection control is indicated on all figures as asterisks above bars.

\section{Competing interests}

The authors declare that they have no competing interests.

\section{Authors' contributions}

PN was responsible for design and completion of the bulk of the research, as well as for data analysis and initial writing of this report. JK was responsible for identification of the Ae. aegypti tRNAval, and contributed critical thinking and planning towards the development of the ribozymes and clones used in the study. TF was responsible for facilitating all cell culture aspects of the research, including establishing, selecting, and maintaining all transduced cell lines. AK and RD were instrumental in providing support to the research in the form of both instruction in and preparation of all lentivirus vectors used in this report. SH was responsible for training and contribution of antibodies and methodologies for all DENV in vitro analyses, and AM contributed expertise towards the Northern blot analyses. VB was responsible for the in vitro ribozyme cleavage analyses. YR and NK were instrumental in securing funding from the Thailand Research Fund and Faculty of Tropical Medicine, Mahidol University, respectively in support of PN. MJF was the Principal Investigator and is primarily responsible for all aspects of the funding, research design, interpretation, and writing of this manuscript. This research was supported by NIH/NIAID RO1 AI48561 to MJF and by the Royal Golden Jubilee Ph.D. program PHD/0175/2543 from the Thailand Research Fund to PN and YR.

\section{Acknowledgements}

The authors would like to thank Dr. Barry Falgout for Dengue virus clones and procedures for their use, and Dr. Charles Rice for helpful discussions in the initial design of this research.

\section{References}

I. Mackenzie JS, Gubler DJ, Petersen LR: Emerging flaviviruses: the spread and resurgence of Japanese encephalitis, West Nile and dengue viruses. Nat Med 2004, 10:598-109.

2. Blair CD, Adelman ZN, Olson KE: Molecular strategies for interrupting arthropod-borne virus transmission by mosquitoes. Clin Microbiol Rev 2000, I3:65 I-6I.

3. Sanchez-Vargas I, Travanty EA, Keene KM, Franz AW, Beaty BJ, Blair $C D$, Olson KE: RNA interference, arthropod-borne viruses, and mosquitoes. Virus Res 2004, 102:65-74.

4. Sabchareon A, Lang J, Chanthavanich P, Yoksan S, Forrat R, Attanath P, Sirivichayakul C, Pengsaa K, Pojjaroen-Anant C, Chambonneau L, Saluzzo JF, Bhamarapravati N: Safety and immunogenicity of a three dose regimen of two tetravalent live-attenuated dengue vaccines in five- to twelve-year-old Thai children. Pediatr Infect Dis J 2004, 23:99-109.

5. Raviprakash K, Liu K, Matteucci M, Wagner R, Riffenburgh R, Carl M: Inhibition of dengue virus by novel, modified antisense oligonucleotides. I Virol 1995, 69:69-74

6. Adelman ZN, Blair CD, Carlson JO, Beaty BJ, Olson KE: Sindbis virus-induced silencing of dengue viruses in mosquitoes. Insect Mol Biol 200I, I 0:265-73.

7. Olson KE, Higgs S, Gaines PJ, Powers AM, Davis BS, Kamrud KI, Carlson JO, Blair CD, Beaty BJ: Genetically engineered resistance to dengue-2 virus transmission in mosquitoes. Science 1996 , 272:884-6.

8. Caplen NJ, Zheng Z, Falgout B, Morgan RA: Inhibition of viral gene expression and replication in mosquito cells by dsRNA-triggered RNA interference. Mol Ther 2002, 6:243-5I.

9. Adelman ZN, Sanchez-Vargas I, Travanty EA, Carlson JO, Beaty BJ, Blair CD, Olson KE: RNA silencing of dengue virus type 2 replication in transformed C6/36 mosquito cells transcribing an inverted-repeat RNA derived from the virus genome. J Virol 2002, 76:12925-33

10. Travanty EA, Adelman ZN, Franz AW, Keene KM, Beaty BJ, Blair CD, James AA, Olson KE: Using RNA interference to develop dengue virus resistance in genetically modified Aedes aegypti. Insect Biochem Mol Biol 2004, 34:607-I3.

II. Franz AW, Sanchez-Vargas I, Adelman ZN, Blair CD, Beaty BJ, James $A A$, Olson KE: Engineering RNA interference-based resistance to dengue virus type $\mathbf{2}$ in genetically modified Aedes aegypti. Proc Natl Acad Sci USA 2006, I03:4198-203.

12. Bull Jj, Jacobson A, Badgett MR, Molineux IJ: Viral escape from antisense RNA. Mol Microbiol 1998, 28:835-46.

13. Cheng GF, Lin JJ, Shi Y, Jin YX, Fu ZQ, Jin YM, Zhou YC, Cai YM: Dose-dependent inhibition of gynecophoral canal protein gene expression in vitro in the schistosome (Schistosoma japonicum) by RNA interference. Acta Biochim Biophys Sin (Shanghai) 2005, 37:386-90.

14. Llave C, Kasschau KD, Carrington JC: Virus-encoded suppressor of posttranscriptional gene silencing targets a maintenance step in the silencing pathway. Proc Natl Acad Sci USA 2000, 97:13401-6.

15. $\mathrm{Li} \mathrm{H}, \mathrm{Li}$ WX, Ding SW: Induction and suppression of RNA silencing by an animal virus. Science 2002, 296:1319-2I.

16. Jackson WH Jr, Moscoso H, Nechtman JF, Galileo DS, Garver FA, Lanclos KD: Inhibition of HIV-I replication by an anti-tat hammerhead ribozyme. Biochem Biophys Res Commun 1998, 245:8I-4.

17. Sun LQ, Wang L, Gerlach WL, Symonds G: Target sequence-specific inhibition of HIV-I replication by ribozymes directed to tat RNA. Nucleic Acids Res 1995, 23:2909-I3.

18. Weinberg M, Passman M, Kew M, Arbuthnot P: Hammerhead ribozyme-mediated inhibition of hepatitis $B$ virus $\times$ gene expression in cultured cells. J Hepatol 2000, 33:|42-5I.

19. von Weizsacker F, Blum HE, Wands JR: Cleavage of hepatitis B virus RNA by three ribozymes transcribed from a single DNA template. Biochem Biophys Res Commun 1992, I 89:743-8.

20. Lieber A, He CY, Polyak SJ, Gretch DR, Barr D, Kay MA: Elimination of hepatitis $C$ virus RNA in infected human hepatocytes by adenovirus-mediated expression of ribozymes. J Virol 1996 , 70:8782-9l.

21. Blount KF, Uhlenbeck OC: The hammerhead ribozyme. Biochem Soc Trans 2002, 30:1 I 19-22.

22. Burke JM: Clearing the way for ribozymes. Nat Biotechnol I997, I 5:4|4-5. 
23. Kato $\mathrm{Y}$, Kuwabara T, Warashina M, Toda H, Taira K: Relationships between the activities in vitro and in vivo of various kinds of ribozyme and their intracellular localization in mammalian cells. J Biol Chem 200 I, 276: 15378-85.

24. Lieber A, Strauss M: Selection of efficient cleavage sites in target RNAs by using a ribozyme expression library. Mol Cell Biol 1995, 15:540-51.

25. Kuwabara T, Warashina M, Koseki S, Sano M, Ohkawa J, Nakayama K, Taira K: Significantly higher activity of a cytoplasmic hammerhead ribozyme than a corresponding nuclear counterpart: engineered tRNAs with an extended ' 3 ' end can be exported efficiently and specifically to the cytoplasm in mammalian cells. Nucleic Acids Res 200I, 29:2780-8.

26. Warashina M, Kuwabara T, Kato Y, Sano M, Taira K: RNA-protein hybrid ribozymes that efficiently cleave any mRNA independently of the structure of the target RNA. Proc Natl Acad Sci USA 200I, 98:5572-7.

27. Kawasaki H, Taira K: Identification of genes by hybrid ribozymes that couple cleavage activity with the unwinding activity of an endogenous RNA helicase. EMBO Rep 2002, 3:443-50.

28. Rossi JJ: Controlled, targeted, intracellular expression of ribozymes: progress and problems. Trends Biotechnol 1995, I3:301-6.

29. Kuwabara T, Warashina M, Tanabe T, Tani K, Asano S, Taira K: A novel allosterically trans-activated ribozyme, the maxizyme, with exceptional specificity in vitro and in vivo. Mol Cell 1998, 2:617-27.

30. Kuwabara T, Warashina M, Nakayama A, Ohkawa J, Taira K: tRNAVal-heterodimeric maxizymes with high potential as geneinactivating agents: simultaneous cleavage at two sites in HIVI Tat mRNA in cultured cells. Proc Natl Acad Sci USA 1999 , 96:1886-9|.

31. Geiduschek EP, Tocchini-Valentini GP: Transcription by RNA polymerase III. Annu Rev Biochem 1988, 57:873-9|4.

32. Cotton M, Birnstiel ML: Ribozyme mediated destruction of RNA in vivo. Embo $\int 1989,8: 386 \mid-6$.

33. Koseki S, Tanabe T, Tani K, Asano S, Shioda T, Nagai Y, Shimada T, Ohkawa J, Taira K: Factors governing the activity in vivo of ribozymes transcribed by RNA polymerase III. J Virol 1999, 73: $1868-77$

34. Craig AW, Haghighat A, Yu AT, Sonenberg N: Interaction of polyadenylate-binding protein with the elF4G homologue PAIP enhances translation. Nature 1998, 392:520-3.

35. Wadhwa R, Ando H, Kawasaki H, Taira K, Kaul SC: Targeting mortalin using conventional and RNA-helicase-coupled hammerhead ribozymes. EMBO Rep 2003, 4:595-60I.

36. Pages JC, Bru T: Toolbox for retrovectorologists. J Gene Med 2004, 6(SuppI I):S67-82.

37. Bartolome J, Castillo I, Carreno V: Ribozymes as antiviral agents. Minerva Med 2004, 95: I I-24.

38. McTaggart S, Al-Rubeai M: Retroviral vectors for human gene delivery. Biotechnol Adv 2002, 20: I-31.

39. Burns JC, Friedmann T, Driever W, Burrascano M, Yee JK: Vesicular stomatitis virus $\mathbf{G}$ glycoprotein pseudotyped retroviral vectors: concentration to very high titer and efficient gene transfer into mammalian and nonmammalian cells. Proc Natl Acad Sci USA 1993, 90:8033-7.

40. Matsubara T, Beeman RW, Shike H, Besansky NJ, Mukabayire O, Higgs S, James AA, Burns JC: Pantropic retroviral vectors integrate and express in cells of the malaria mosquito, Anopheles gambiae. Proc Natl Acad Sci USA 1996, 93:6181-5.

41. Buchschacher GL Jr: Introduction to retroviruses and retroviral vectors. Somat Cell Mol Genet 200 I, 26: I- II.

42. Hotchkiss G, Maijgren-Steffensson C, Ahrlund-Richter L: Efficacy and mode of action of hammerhead and hairpin ribozymes against various HIV-I target sites. Mol Ther 2004, 10:172-80.

43. Wyszko E, Barciszewska MZ, Bald R, Erdmann VA, Barciszewski J: The specific hydrolysis of HIV-I TAR RNA element with the anti-TAR hammerhead ribozyme: structural and functional implications. Int J Biol Macromol 200I, 28:373-80.

44. Dan M, Wang AL, Wang CC: Inhibition of pyruvate-ferredoxin oxidoreductase gene expression in Giardia lamblia by a virus-mediated hammerhead ribozyme. Mol Microbiol 2000, 36:447-56.
45. Chen L, Li J, Zhang X, Liu Q, Yin J, Yao L, Zhao Y, Cao L: Inhibition of krrl gene expression in Giardia canis by a virus-mediated hammerhead ribozyme. Vet Parasitol 2007, 143:14-20.

46. Grassi G, Forlino A, Marini JC: Cleavage of collagen RNA transcripts by hammerhead ribozymes in vitro is mutation-specific and shows competitive binding effects. Nucleic Acids Res 1997, 25:345|-8.

47. Jarvis TC, Bouhana KS, Lesch ME, Brown SA, Parry TJ, Schrier DJ, Hunt SW 3rd, Pavco PA, Flory CM: Ribozymes as tools for therapeutic target validation in arthritis. J Immunol 2000, 165:493-8.

48. Gitlin L, Karelsky S, Andino R: Short interfering RNA confers intracellular antiviral immunity in human cells. Nature 2002 , 418:430-4.

49. Li WX, Ding SW: Viral suppressors of RNA silencing. Curr Opin Biotechnol 200I, I 2:150-4.

50. Das AT, Brummelkamp TR, Westerhout EM, Vink M, Madiredjo M, Bernards R, Berkhout B: Human immunodeficiency virus type I escapes from RNA interference-mediated inhibition. J Virol 2004, 78:260I-5.

5I. Kuwabara T, Warashina M, Taira K: Cleavage of an inaccessible site by the maxizyme with two independent binding arms: an alternative approach to the recruitment of RNA helicases. $J$ Biochem. 2002, I32(I): 149-155.

52. Tanabe T, Takata I, Kuwabara T, Warashina M, Kawasaki H, Tani K, Ohta S, Asano S, Taira K: Maxizymes, novel allosterically controllable ribozymes, can be designed to cleave various substrates. Biomacromolecules 2000, I:108-17.

53. Zuker M: Mfold web server for nucleic acid folding and hybridization prediction. Nucleic Acids Res 2003, 31:3406-15

54. Thompson JD, Gibson TJ, Plewniak F, Jeanmougin F, Higgins DG: The CLUSTAL $X$ windows interface: flexible strategies for multiple sequence alignment aided by quality analysis tools. Nucleic Acids Res 1997, 25:4876-82.

55. Chenna R, Sugawara H, Koike T, Lopez R, Gibson TJ, Higgins DG Thompson JD: Multiple sequence alignment with the Clustal series of programs. Nucleic Acids Res 2003, 31:3497-500.

56. Kolokoltsov AA, Weaver SC, Davey RA: Efficient functional pseudotyping of oncoretroviral and lentiviral vectors by Venezuelan equine encephalitis virus envelope proteins. J Virol 2005, 79:756-63.

57. Shao Y, Wu S, Chan CY, Klapper JR, Schneider E, Ding Y: A structural analysis of in vitro catalytic activities of hammerhead ribozymes. BMC Bioinformatics 2007, 8:469.

58. Henchal EA, McCown JM, Burke DS, Seguin MC, Brandt WE: Epitopic analysis of antigenic determinants on the surface of dengue-2 virions using monoclonal antibodies. Am J Trop Med Hyg 1985, 34:162-9.

59. Karber G: 50\% end-point calculation. Arch Exp Pathol Pharmak 1931, 162:480-483.
Publish with Biomed Central and every scientist can read your work free of charge

"BioMed Central will be the most significant development for disseminating the results of biomedical research in our lifetime. "

Sir Paul Nurse, Cancer Research UK

Your research papers will be:

- available free of charge to the entire biomedical community

- peer reviewed and published immediately upon acceptance

- cited in PubMed and archived on PubMed Central

- yours - you keep the copyright
BioMedcentral 